\title{
TRANSGRESSIVE AND REGRESSIVE CRETACEOUS DEPOSITS IN SOUTHERN SAN JUAN BASIN, N. MEX.
}

\author{
By Julian D. Sears, C. B. Hunt, and T. A. Hendricks
}

\begin{abstract}
In explanation of the large-scale intertonguing of marine and continental deposits shown by the Mancos shale and the Mesaverde formation in the southern part of the San Juan Basin, N. Mex., and of the marked variations in the stratigraphic boundary between those formations, the paper offers views as to sedimentation processes that are believed not only to account for the features observed in this field but also to be applicable in the interpretation of similar deposits in many other fields. Three successive series of beds, each comprising a sequence of marine, near-shore, coastal, flood-plain, coastal, near-shore, and marine deposits, are evidence of three transgressions and regressions of the Upper Cretaceous sea. The writers have endeavored to visualize the conditions and processes of land and sea movement and of sedimentation that would bring about such repeated transgressions and regressions and the deposition and preservation of materials in such sequences.
\end{abstract}

The paper is divided into three sections: First, a presentation of the depositional concept held by the writers, with reasons for its adoption; second, a description of the nature, relations, and variations of the Mancos and Mesaverde in the southern part of the San Juan Basin; and third, an outline of the inferred depositional history of these formations.

According to the concept presented, deposition took place in a broad, shallow trough or geosyncline, the middle, deeper part of which was occupied by a shallow sea, which at times spread over the adjacent lowlands and at times withdrew to the middle zone. Those transgressions and regressions of the sea are recorded in the alternations of marine and continental deposits around the margins of the trough. The writers accept the usual view that the advances of the sea and the development of transgressive deposits were brought about by a sinking of the trough. They do not, however, accept as applicable in this and similar cases the frequently expressed view that retreats of the sea and the development of regressive deposits were brought about by a reversal of the movement-that is, by a rising of the trough. Instead, they believe that both the regressions and the regressive deposits were due to a process of trough filling that operated during periods when the rate of sinking of the trough was much reduced and when the supply of debris was sufficient to build the near-shore deposits upward to and above the water surface and also outward, thus forcing the sea to retreat. As the result of continued, though slower, subsidence there was room beneath the profile of equilibrium for the quiet, conformable deposition of thick near-shore sands upon the older off-shore muds without erosion of the older material through wave action. This is shown by the widespread occurrence of transition zones between shale and overlying regressive sandstone, and by the extent, thickness, and uniformity of such sandstones. With continued subsidence there would also be opportunity for the development of thick coal-bearing coastal-swamp deposits behind and encroaching upon the beach sands as the sands grew upward and senward. On the contrary, a reversal of move- ment with rise of the trough would bring at least a part of the previous transgressive deposits up into the zone of subaerial and subaqueous erosion and would almost surely not permit thick and widespread regressive deposits to be laid down on them and preserved. Moreover, in a broad structural downfold or trough, the natural tendency of further epeirogenic movement would be in a continuous downward direction, and frequently repeated reversals or up-and-down movements of the trough would appear to be so unlikely that they should not be postulated unless unmistakably required by evidence in the rocks.

In the southwestern part of the San Juan Basin, near Gallup, the Mancos shale is 725 . feet thick and consists principally of more or less sandy shale with several subordinate sandstones. Overlying it is about 1,800 feet of the Mesaverde; the upper part of the formation has been removed by erosion. The Mesaverde comprises sandstones, clays, and coal beds, and is predeminantly of continental origin. In this area it has been divided into five units, named in ascending order the Gallup sandstone member, the Dilco coal member, the Bartlett barren member, the Gibson coal member, and the Allison barren member. From the vicinity of Gallup eastward across the southern edge of the basin the lower thousand feet of the Mesaverde (representing the units from the Gallup sandstone member to the Gibson coal member, inclusive) show great progressive changes. At first, two new massive sandstones appear in the section; of these, the Dalton replaces the upper part of the Dilco coal member, and the Hosta splits the Gibson coal member into two parts. Moreover, the lower third of the Gallup is divided and in part replaced by wedges of Mancos shale. Farther east, a tóngue of shale, the Mulatto, comes in between the Dilco and the Dalton, and a higher tongue of shale, the Satan, splits the Hosta sandstone member. These two shale tongues thicken steadily eastward. Concurrently, the intervening units of the Mesaverde grow thinner, and some die out; in the southeastern part of the basin even their most persistent layers, two thin sandstones that represent, respectively, the Gallup and a union of the Dalton and lower Hosta, become nothing more than sandy zones in the midst of a great body of shale about 2,000 feet thick. That shale body, a union of the thin Mancos farther west with the greatly expanded Mulatto and Satan tongues, forms the Mancos of the southeastern and eastern parts of the basin. It is directly overlain by the upper part of the Hosta sandstone, which in that part of the field marks the base of the restricted Mesaverde. Thus the Mancos-Mesaverde boundary rises stratigraphically about 1,200 feet in a distance of 100 miles from west to east-a direction that is basinward but oblique to the trends of the aucient shore lines.

The depositional history of the three transgressive and three regressive stages that are recorded in the rocks of the Mancos and Mesaverde is outlined in the concluding section or tne paper, in accordance with the general concept of depositional processes herein presented. 


\section{INTRODUCTION}

\section{PURPOSE AND SCOPE OF THE PAPER}

Large-scale intertonguing of marine and continental deposits has been observed at many places and in many formations, and its significance as a record of successive. advances and retreats of the ancient sea has long been recognized. However, the cause of these advances and retreats and the conditions under which the material was laid down and preserved have been explained in different ways. In general, the transgressive processes and deposits have been satisfactorily analyzed by many writers, but the regressive processes and the regressive deposits seem less thoroughly understood and are believed to merit further study and discussion.

The Mancos and Mesaverde formations in the southern part of the San Juan Basin, N. Mex., afford excellent examples of such large-scale intertonguing. Within the area mapped by the writers ${ }^{1}$ in 1929, 1930, and 1931, there are three successive series of beds, each comprising a stratigraphic sequence of marine, near-shore, coastal, flood-plain, coastal, near-shore, and marine deposits. These three series are clearly a record of three transgressions and three regressions of the Upper Cretaceous sea. The problem is: What were the conditions and processes of land and sea movement and of sedimentation that would bring about such repeated transgressions and regressions and the deposition and preservation of materials in such sequence? Study of this problem led the writers to a concept of sedimentation processes which in their judgment accounts satisfactorily for the features observed in the San Juan Basin. and which they believe to be applicable also in the interpretation of similar deposits in many other fields.

\section{ARRANGEMENT OF THE PAPER}

The main body of the paper is divided into three sections-first, a presentation of the concept held by the writers, with reasons for its adoption; second, a description of the rock units that make up the Mancos and Mesaverde in the southern part of the San Juan Basin; and third, an outline of the depositional history of the two formations as interpreted in accordance with the writers' concept of the processes.

\section{DEPOSITIONAL THEORIES}

\section{GENERAL CONDITIONS}

The concept here presented relates to deposition in the broad, shallow trough or geosyncline that occupied the western part of our country during Upper Cretaceous time, and it is believed "to be applicable to other similar troughs. The concept does not relate to deposition on the continental shelf, facing, the ocean deeps,

1 Sears, J. .D., The coal feld from Gallup eastward toward Moun Taylor: U. S. Geol. Survey Bull. 860, pp. 1-29, 1934. Hunt, C. B., The Mount Taylor coal field : U. S. Geol. Survey Bull. 860, pp. 31-80, 1936. for there the conditions, the processes, and the final results would probably be markedly different.

The Upper Cretaceous rocks of the western interior: region were laid down in a trough that extended north and south for several thousand miles and had an average width of roughly a thousand miles. During most of the period the middle or deeper part of the trough was occupied continuously by a shallow sea, irregular in shape and variable in size. At times this sea was enlarged and spread far and wide over the gentle slopes of the adjoining land, only to withdraw again to the deeper middle part. A record of these repeated advances and retreats of the sea is preserved in the variations of the rocks laid down at successive stages and is most clearly revealed in the intertonguing of continental and marine deposits found at many places around the margins of the ancient trough.

\section{SIGNIFICANCE OF SHIFTS OF THE STRAND LINE}

Whether or not each of the successive advances and withdrawals of the sea was essentially simultaneous over the entire region is a question beyond the scope of this paper-indeed, it could not be answered conclusively in the present state of knowledge. But the regional causes as well as the local modifying influences that produced the advances and retreats-the repeated landward and seaward shifts of the strand line-must be sought and considered.

The explanations usually offered for such shifts of the strand line reflect two widely held but conflicting views regarding earth movements and sedimentation. One view postulates frequently repeated up-and-down movements of the trough in relation to sea level. According to this view, a sinking of the trough (including those marginal parts that are above water) and a consequent deepening of the sea bring an advance of the sea and transgressive deposition of marine material over the land surface; and a rising of the trough and a consequent shallowing of the sea cause a withdrawal of the sea, a seaward migration of the strand line, and regressive deposition of near-shore and continental material on the earlier marine deposits.

The second view recognizes that a sinking of the trough and a consequent deepening of the sea would cause advance of the sea and transgressive deposition of marine material over an older land surface. It seriously questions, however, the concept of frequent vertical oscillations of the trough in relation to sea level; and for regressive deposits of the type herein described it prefers the concept that gradual filling of the trough and outward growth of the land by near-shore deposition cause a seaward shifting of the strand line and a forcing back of the sea.

Thus, by the first view, regressive deposits are the result of a seaward migration of the strand line, whereas, by the second view, they are the cause of the seaward 
migration of the strand line. However, the differences between the two views are not in general sharply defined, and in many reports in which regressive deposits are considered their mode of origin is either ignored or: only vaguely discussed.

\section{CONDITIONS OF REGRESSIVE DEPOSITION}

The writers wish to make clear at the outset their belief that the regressive deposits of the Upper Cretaceous described in this paper resulted from a process of trough filling - a building up of the near-shore deposits to and above sea level by which the strand line was gradually forced outward and the sea was restricted to narrower limits. They believe that this process was effective during periods when the sinking of the trough and the consequent tendency of the sea to deepen, though continuing, were slowing down, perhaps almost to a temporary standstill. They believe, further, that a retreating and shallowing sea caused by a rising trough would not be likely to permit the formation and preservation of regressive deposits of the type found in the San Juan Basin.

Some reasons for these beliefs have been outlined briefly by the senior author. ${ }^{2}$ Others are revealed by the nature and relations of the sedimentary rocks described herein. The reasons fall into three principal groups, which are summarized in the following three paragraphs.

First: During periods when the sinking of the trough, though continuing, was at a slower rate the conditions would be favorable to the accumulation and preservation of regressive deposits. With the sea still having a general tendency to deepen because of the subsidence, room would be provided beneath the profile of equilibrium ${ }^{3}$ for the deposition of the newer near-shore sands upon the older offshore muds without erosion of the carlier material through wave action or disturbance of the newer material during deposition. Such conditions would be necessary to account for the widely observed transition zones of alternating thin, regular layers of sandstone and shale that mark the change from marine shales to overlying regressive sandstones and that are evidence of undisturbed, conformable deposition. Moreover, during further gradual sinking there would continue to be sufficient room beneath the profile of equilibrium for the marine part of the regressive sands to attain the considerable thickness and wide extent that are characteristic of these deposits. Once formed, these sands would be preserved by the laying down upon

\footnotetext{
Sears, J. D., Regressive sandstones: Washington Acad. Sci. Jour. vol. 23 , pp. 397-398, 1933 .

a The profile of equilibrium is a horizon * * at which, if and when nttrined, deposition and erosion are balanced for the existing conditions. Sea bottoms above the profile of equilibrium are subject to scour, those below the profile are subject to sedimentation (Eaton, T. E., The by-passing and discontinuous deposition of sedimentary materials: Am. Assoc. Petroleum Geologists Bull., vol. 13, pp. 714-715, 1920).
}

them of still younger deposits. Along the shore the excess of sand would result in the building up of beaches and barrier reefs not only to and above sea level but also outward; and by this outward growth the strand line would be moved seaward and the sea be forced back. Furthermore, in the outward growth of the sand body its upper surface, because of the continuing trough subsidence, would rise seavard in relation to the old land surface and the trough floor; that is, the most recently deposited beach sand would lie at a higher altitude than the sand of the earlier beaches farther inland, which by that time had been affected by the general subsidence. This landward slope or seaward rise of the upper surface of the sand would have two effects-(1) it would contribute to the thickness of the regressive sandstone as a whole and (2) it would bring about, in the sinking zone landward from the beach, conditions that are favorable to the accumulation of thick coal-bearing deposits in swamps whose upper surface would remain near sea level. These conditions and the processes suggested in the foregoing statement are illustrated in plate 25 , which shows, according to the writers' concept, the change from transgressive to regressive deposition caused by a decrease in the rate of trough subsidence. The successive diagrams show the cumulative effect of additional subsidence. The transgression, partly accomplished.in diagram $\mathrm{A}$, is continued in diagrams $\mathrm{B}$ and $\mathrm{C}$ where subsidence (drawn arbitrarily as 50 feet per: unit period and carrying the old land surface down to levels marked $b$ and $a$ ) predominates over sedimentation. Diagrams $\mathrm{D}, \mathrm{E}$, and $\mathrm{F}$ (with subsidence reduced to a rate of 20 feet per unit period) represent a time when sedimentation predominates over subsidence, the result being retreat of the sea through the deposition of regressive material.

Second : A reversal of the movement and a rise of the trough would bring about conditions not generally favorable to the accumulation and preservation of regressive deposits of the type here discussed; and the greater the magnitude or duration of the reversal the more unfavorable would be the conditions. In the initial stages of the rise of the trough and the consequent shallowing and retreat of the sea the near-shore and off-shore deposits of the previous transgression would be lifted nearer to the surface of the water or even above it, and thus they would be exposed to subaerial and subaqueous erosion before any regressive material could be laid down upon them. (In the San Juan Basin there was found no evidence of any appreciable erosion of that type; on the contrary, there is widespread evidence that the newer near-shore sand was laid down conformably upon the older off-shore mud.) With continuing rise of the trough and shallowing of the sea the earlier deposits farther away from the shore would be raised higher and higher above the profile of equilibrium and 
into the reach of effective wave action; additional erosion of the earlier material by marine scour would therefore seem more probable than permanent deposition of more material on it. Moreover, even though a regressive sandstone was being formed, the continuing rise of the trough would bring the landward parts of the sandstone farther and farther above sea level and thus make difficult if not impossible the accumulation upon them of thick coastal-swamp coal-bearing deposits. It is conceded that in certain circumstances (for example, during a small slow rise after a transgression in which the supply of debris had been insufficient to keep the deposits up to the profile of equilibrium) some regressive deposition might accompany or reșult from a rise of trough; but such deposits would probably be rather thin and local. To the writers it seems very unlikely that a rising trough and shallowing sea could be the general environment for or explanation of the accumulation and permanent preservation of thick regressive sandstones that are in major part of uiider-water origin, that stretch in great uniform sheets for hundreds of miles along shore and extend for 50 to 100 miles seaward, and that are overlain by thick deposits of coastal swamp and estuarine origin.

Third: Continued subsidence of the trough seems mechanically more likely than frequent reversals of the direction of its movement. In a broad structural trough or geosyncline, such as that in which the Upper Cretaceous rocks were laid down, the natural tendency of epeirogenic movement probably would be in a single direction. Once downfolding has begun, further movement probably would follow the downward course, whether the cause of the movement: were isostasy or lateral pressure, and whether the movement were uniform or a differential warping. True, the subsidence probably would be intermittent as stresses grow and are relieved. However, it seems illogical to postulate frequent reversals of the direction of movement unless they aive unmistakably recorded by the deposits or are required to explain them-conditions not true in the San Juan Basin.

\section{TRANSGRESSIVE AND REGRESSIVE STAGES}

The writers believe that vertical movement continued in a single direction; that, with slow subsidence of the trough floor and of the nearby land, the sea maintained its general tendency to deepen; and that the variations consisted only of variations in the rate of trough subsidence and of supply of debris. According to this concept, the formation of transgressive and regressive deposits depends upon relative rates of sinking and of sedimentation. When sinking predominates, there is transgression; when sedimentation prevails, regression and regressive deposits are the result. Any increase or decrease in the rate of supply of debris merely has an effect equivalent to that of some decrease or increase, respectively, in the rate of subsidence. For the sake of simplicity, therefore, in this paper the rate of supply of debris is assumed to be constant, and emphasis is put on the variations in the rate of subsidence.

Around the margins of the trough at any one time there were four zones of deposition-(1) an off-shore zone, extending far out into the trough but with water probably never very deep, in which muds and clays with much marine organic material were being deposited; (2) a near-shore zone in which sands and locally some pebbles were being laid down below, at, and just above water level; (3) a coastal zone of swamps, lagoons, and estuaries in which at many places moderately thick coal beds were formed amid drab clays and irregular sand bodies containing more or less peaty material; and (4) a landward zone in which were laid down, and in part preserved, flood-plain deposits of highly irregular, more or less cross-bedded, and in places conglomeratic sand, gray and light-tinted clay largely of the "badlands" type, and only a very few scattered thin lenses of coal.

During periods when subsidence of the trough was fairly rapid, the deepening of the sea was too fast for the supply of debris; the water advanced gradually over the land, and the position of the four zones shifted progressively landward. The material of each zone thus came to be overlain by a layer of the material characteristic of the zone next toward the sea; a layer of the coastal plain deposits, itself being extended landward, became overlain by a growing sheet of near-shore sandy deposits, and those in turn became covered by muds and clays of the advancing off-shore zone. The deposits representing any one zone are progressively younger and rise across planes of time equivalence in a landward direction. (See fig. 20.) This was normal transgressive deposition, which continued as long as the controlling conditions remained unchanged. The time during which this process continued may be referred to as a transgressive stage.

Eventually, however, the subsidence of the land and the deepening of the sea, though still continuing, gradually slowed down to a considerably lower rate. If the supply of sediment continued unabated, there came a time when its deposition began to gain on the sea, which then could no longer encroach on the land, but on the contrary was gradually pushed backward by a slow outward growth of the near-shore deposits. The several zones of deposition began a slow march seaward, each zone in turn leaving its typical deposits above those of the zone that had retreated. As the near-shore sands, built up to and above water level, gradually extended seaward, their landward portions became the sites of coastal swamps and lagoons, which superimposed their typical deposits, only to be covered in turn by the floodplain materials left by the rivers that extended their 
lower courses over the new land reclaimed from the sea. Under these conditions the deposits representing any one zone are progressively younger and rise across planes of time equivalence in a seaward direction. (See fig. 20.) This, in the writers' view, is the method by which regressive deposits of the Upper Cretaceous in the San Juan Basin were formed and preserved. The major types of rocks are logically mapped as the stratigraphic boundaries of these units; and if such changes are found at different horizons from place to place, because of variation in the sediments, the boundaries are free to move correspondingly upward or downward.

Flexible boundaries of this type are characteristic of the Mancos and Mesaverde strata. Widespread ad-

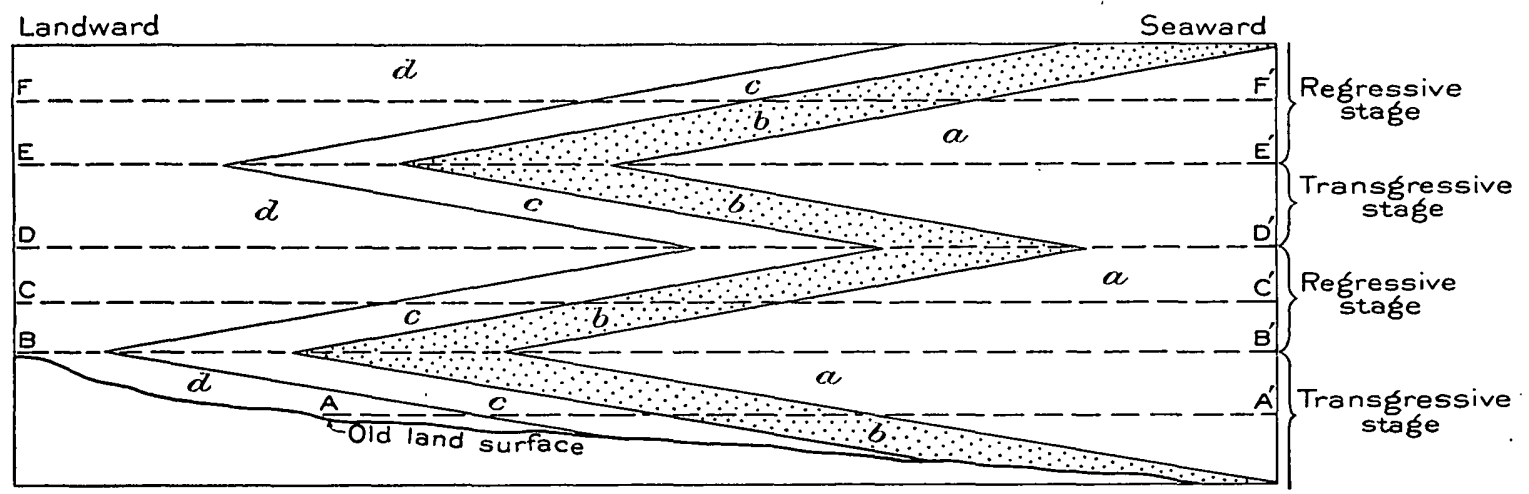

Ficun 20.-Dingrum showing the relations of transgressive and regressive deposits and stages to planes of time eguivalence. $a$, Marine muls; $b$, near-shore sands; $c$, constal deposits; $d$, flood-plajin deposits : $\mathbf{A}-\mathbf{A}^{\prime}, \mathbf{B}-\mathbf{B}^{\prime}$, etc., planes of time equivalence.

time during which this process continued may be referred to as a regressive stage. It persisted until an acceleration of subsidence and water deepening began a new marine invasion and a new sequence of transgressive deposits.

\section{DESCRIPTION OF MANCOS SHALE AND MESAVERDE FORMATION IN SOUTHERN SAN JUAN BASIN}

\section{SIGNIFICANCE OF THE FORMATION NAMES}

The names Mancos shale and Mesaverde formation or group have long been applied to two great series of beds of Upper Cretaceous age that underlie thousands of square miles in Wyoming, Colorado, Utah, Arizona, and New Mexico. Recent years, however, have brought increasing realization that the formations thus named, though in a general way continuous, are far from uniform over this whole vast region; on the contrary, they vary markedly from place to place in age, thickness, lithology, and interrelations. In any consideration of these rocks it is therefore essential to have clearly in mind the precise significance of their names and their identity.

Both by original definition and by most later usage, the two formations are differentiated solely on the basis of their lithologic character, the Mancos being predominantly fissile clay shale and the Mesaverde an alternating series of irregularly bedded sandstone, clay, and coal. Their definition does not include the criterion of precise age limits, nor does it depend specifically upon the factor of depositional environment, though the Mancos is wholly or mostly a marine deposit and the Mesaverde is largely of continental origin. For this reason the horizons of sharpest change between the vances and retreats of the Upper Cretaceous sea are recorded by the many vertical and lateral variations in the deposits. Fine muds of the Mancos continued to be laid down in some areas long after deposition of rocks of the Mesaverde type had begun in other areas. Thus the stratigraphic position of the lithologic change varies from place to place, and hence the boundary between the two formations in a general way cuts obliquely across planes of time equivalence. However, the boundary is not a simple plane but is complicated by smaller-scale intertonguing of the two types of rock. Such a serrate, rising or falling boundary between Mancos and Mesaverde has already been observed in other areas-for example, in the Rock Springs uplift, Wyoming, ${ }^{4}$ and in the Book Cliffs in Utah ${ }^{5}$ and Colorado. ${ }^{6}$

It should be emphasized, therefore, that the Mancos and Mesaverde are lithologic units-formations whose general rock characteristics persist over great areas but whose composition, thickness, boundaries, and age vary considerably from place to place. In earlier years these formations were identified in many separate fields on the basis of their lithologic resemblance and their comparable age, supplemented in some instances by reconnaissance tracing between the fields. 'This sufficed to give a broad outline of the nature and distribution of

4 Sears, J. D., Geology of the Baxter Basin gas field, Sweetwater County, Wyo.: U. S. Geol, Survey Bull. 781, pp. 20-21, PIs. 4, 5, 1926.

'Clark, F. R., Economic geology of the Castlegate. Wellington, and Sunnyside quadrangles, Carbon County, Utah: U. S. Geol. Survey Bull. 793, pp. 14-15, P1. 4, 1928. Fisher, D. J., The Book Cliffs coal field in Emery and Grand Counties, Utah: U. S. Geol. Survey Bull. 852, pp. 11-16, Pl. 7, 1936.

- Irdmann, C. E., The Book Cliffs coal field in Garfieid and Mesa Counties, Colo.: U. S. Geol. Survey Bull. 851 , pp. 30-44, PI. 4, 1934 , 
the formations over a great region and pointed out the major differences from one field to another, but it did not show how the changes took place. Gradually more detailed work has filled in many of the gaps in the picture. Careful tracing has demonstrated the lateral gradations and intertonguing of the sediments, the manner in which the boundaries between them rise or fall, and the more precise age relations of the component beds. Though the general picture is still far from complete, each contribution to it has not only been of stratigraphic importance by modifying or confirming the earlier correlations, but has also provided invaluable material for those interested in the broader studies of historical geology and sedimentation.

Recent field work of the Geological Survey has thrown new light on the character, variations, and relations of the Mancos and Mesaverde in the southern part of the San Juan Basin, N. Mex. The information thus acquired explains some of the apparent inconsistencies in the earlier observations, and places the correlation upon a firmer basis. It shows that from west to east the rise in stratigraphic position and hence in age of the Mancos-Mesaverde boundary is much greater than had hitherto been suspected, and also that the boundary is complicated by large-scale intertonguing of the two formations. Furthermore, it offers valuable evidence for interpreting the geologic history of the region, the conditions of sedimentation, and the shifting of lands and seas.

\section{FIELD STUDIES}

The first application of the names Mancos and Mesaverde to beds in the southern part of the San Juan Basin seems to have been made by Shaler, ${ }^{7}$ who in 1906 carried out a rapid reconnaissance of the west side of the basin. During the preceding year he had accompanied. Schrader ${ }^{8}$ in an even more rapid trip around the border of the entire basin, but their observations were insufficient even for tentative correlation, and Schrader referred to the formations in the south merely as beds of Montana and Colorado age. On his second trip Shaler was able to demonstrate the general relations; however, influenced by fragmentary paleontologic evidence and with the lithologic variations not traced in detail, he included in his southern Mancos a thick zone of sandstones, clays, and coal beds which are now placed in the Mesaverde formation.

In 1907 and 1908 Gardner $^{9}$ made somewhat more detailed studies of the coal field in the southern part of

\footnotetext{
${ }^{7}$ Shaler, M. K., A reconnaissance survey of the western part of the Durango-Gallup coal field of Colorado and New Mexico: U. S. Geol. Survey Bull, 316, pp. 376-426, 1907.

${ }^{3}$ Schrader, F. C., The Durango-Gallup coal field of Colorado and New Mexico: U. S. Geol. Survey Bull. 285, pp. 241-258, 1906.

- Gardner, J. H., The coal fleld between Gallup and San Mateo, N.

Mex. : U. S. Geol. Survey Bull. 341, pp. 364-378, 1909. The coal fleld between San Mateo and Cuba, N. Mex, : TI, S, Geol, Survey Bull. 381, pp, $461-473,1910$.
}

the basin, from Gallup to Cuba, N. Mex. His differentiation of the Mancos and Mesaverde was based on Shaler's views. However, because his attention was focused on the coal deposits, he did not note the complex intertonguing and the great rise of the Mancos-Mesaverde boundary from west to east; hence his correlation of the smaller units became confused and the lower zone of sandstones and coal beds was placed in the Mancos in some areas and in the Mesaverde in others.

Detailed mapping in the Gallup coal district was carried on by the senior author in 1919 and 1920. At that time he became convinced that the proper MancosMesaverde boundary in that area was lower than the horizon at which it had been placed by Gardner and others. In his report ${ }^{10}$ this view was stated as follows:

In the Gallup-Zuni Basin the upper limit of the (Mancos) formation should be placed at the bottom of the massire sandstone that forms the crest of the west ridge of the Hogback. Thus limited, the formation consists mainly of dark-gray, somewhat sandy marine shale. *** Near the top is a transition zone of sandy shale, shaly sandstone in layers averaging 1 inch thick, and a 20-foot bed of buff "muddy" sandstone. On the west side of the basin and in the anticline at Defiance Switch the transition zone is thicker and contains several conspicuous sandstones, of which the uppermost has the same "muddy" appearance as that in the Hogback. Some of the earlier workers in the field have extended the Mancos shale to include the overlying 250 feet of sandstone, shale, and coal, which in this report is called the basal member of the Mesaverde formation. The Mancos-Mesaverde boundary has never been traced in detail from the type locality in Colorado, and the paleontologic evidence is insufficient to decide the question. The writer is of the opinion, therefore, that in the Gallup-Zuni Basin the boundary should be drawn at the horizon where an abrupt change in lithology indicates a change in mode of deposition. Such a change occurred with the laying down of the massive basal sandstone of the Mesaverde as here defined, and wast foreshadowed by the deposition of the transition beds in the upper part of the Mancos shale. $* * *$ Taking into consideration the thickness, the lithology, and the mode of origin of the formations in the Gallup Basin, the writer believes that the Mancos shale and the Mesaverde formation as here defined are homogenetic equivalents of the formations in Coloradothat is, they were formed under the same conditions and at the same relative place in the stratigraphic section; but that the Mesaverde rocks were already being laid down in what is now the Gallup-Zuni Basin while Mancos shale was still forming farther north.

The information upon which the present paper is based was gathered during a detailed examination of the coal beds in the southern part of the San Juan Basin carried out by the authors in the field seasons of 1929 , 1930, and 1931. In 1929 the party was in charge of Mr. Sears for the first 3 months and of Mr. Hendricks for the succeeding 2 months. In 1930, after a month's direction by $\mathrm{Mr}$. Sears, the party was in charge of $\mathrm{Mr}$. Hunt, who also continued the examination in 1931.

${ }^{10}$ Sears, J. D., Geology and coal resources of the Gallup-Zuni Basin, N. Mex. : U. S. Geol. Survey Bull. 767, pp. 14-15, 1925. 


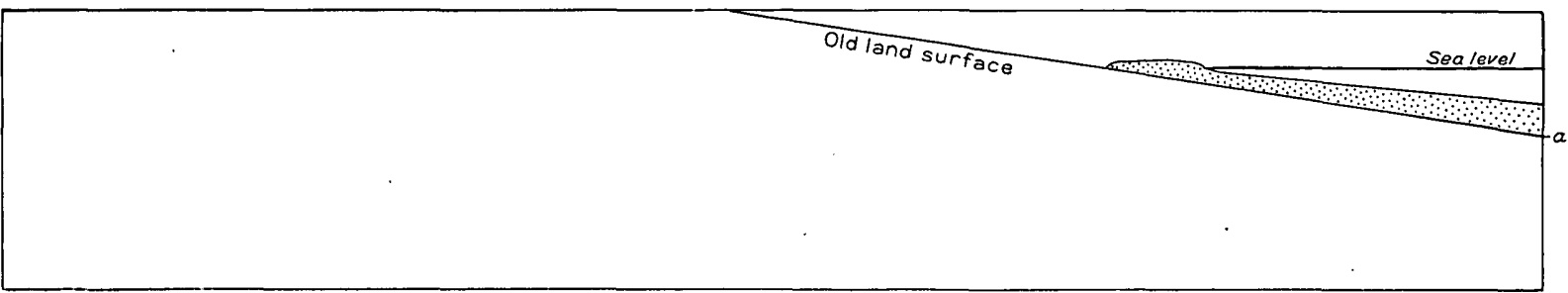

A
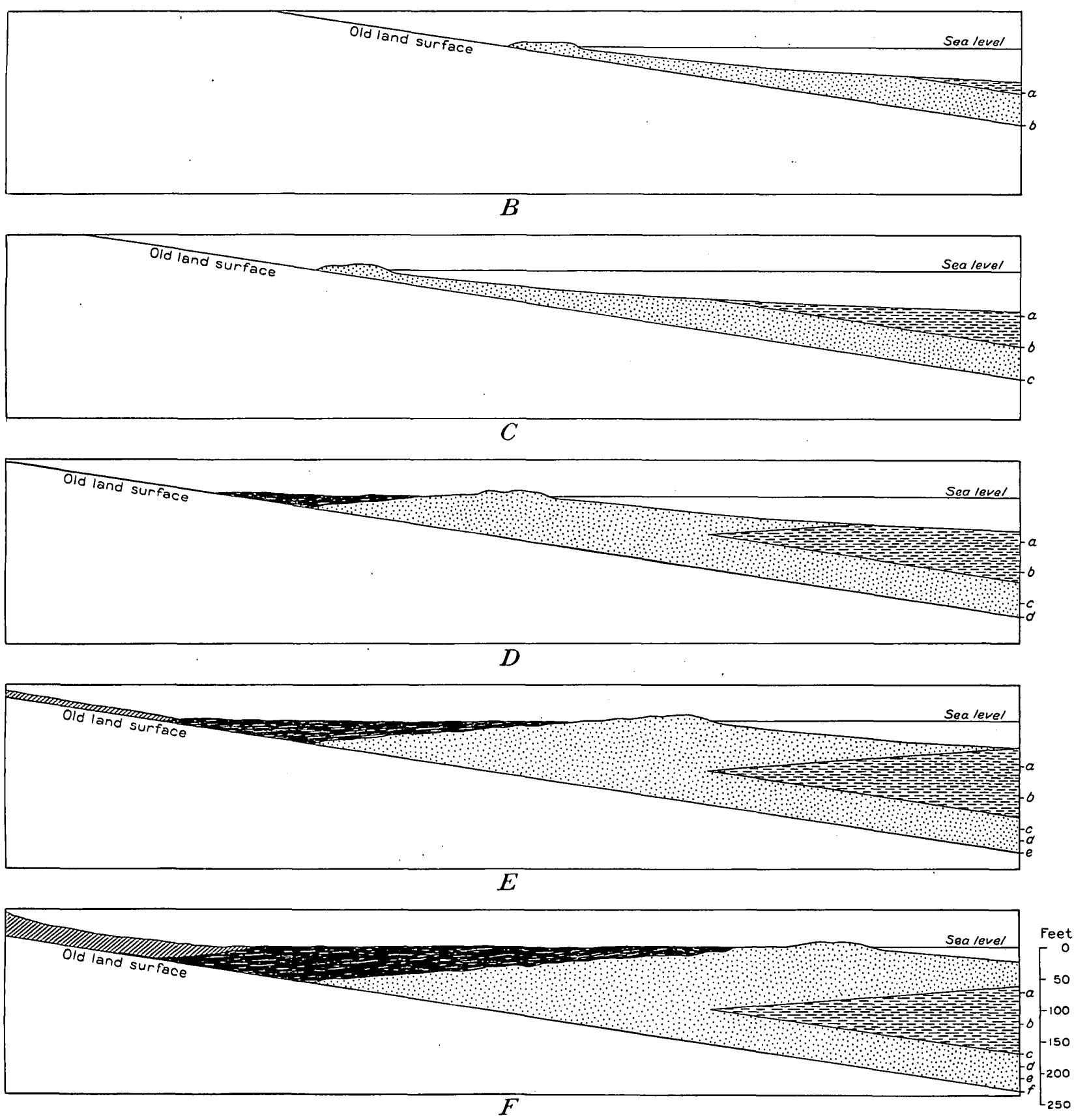

25

20

15 Scale in miles

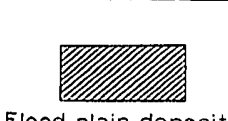

EXPLANATION

Flood-plain deposits

Coastal swamp deposits,

Beach and near-shore sands

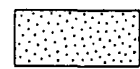

coal-bearing

DIAGRAMS SHOWING CHANGE FROM TRANSGRESSIVE TO REgRESSIVE DEPOSITION 'IHROUGH DECREASE IN RATE OF TROUGH SUBSIDENCE. 
The area thus examined is shown in figure 21. The survey began at the western edge, adjoining the Gallup district, and was largely concerned with the tracing of the formations and their subdivisions as defined and the rock members were mapped, about 250 stratigraphic sections were measured, and about 200 fossil collections were made. For information as to the areal and structural geology of the field and to its coal deposits and

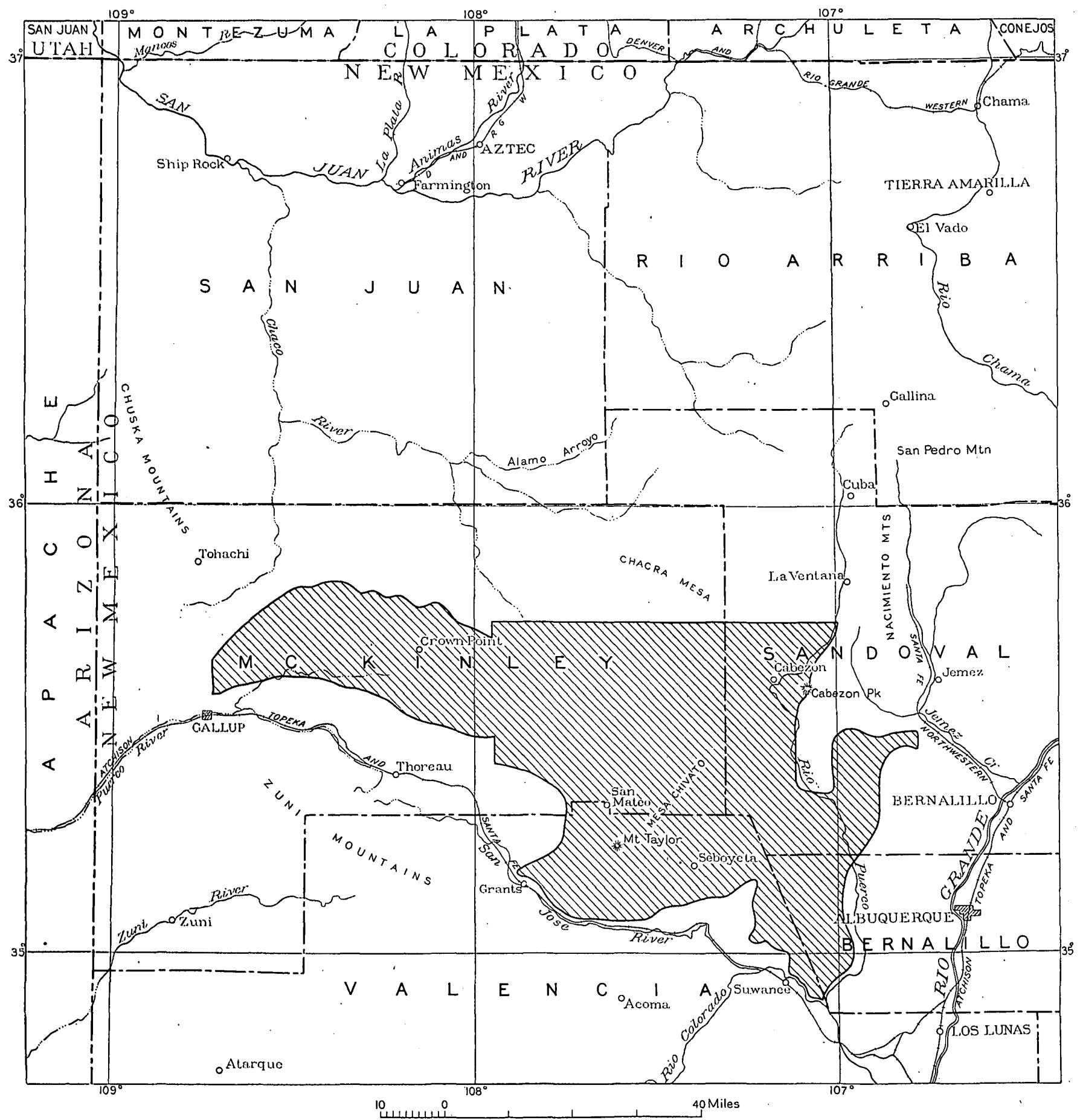

Figure 2.1.-Index map showing location and extent of the area discussed in this paper.

named in that district. The work was continued eastward across the southern part of the San Juan Basin to Grants and La Ventana, including also the blockfaulted area adjacent to the southeast corner of the basin. During the course of the survey the boundaries between possibilities for oil and gas, readers are referred to two other reports ${ }^{11}$ and their accompanying geologic maps.

11 Sears, J, D, The coal field from Gallup eastward toward Mount Taylor: U. S. Geol. Survey Bull. 860, pp. 1-29, 1934. Hunt, C. B., The Mount Taylor coal field: U. S. Geol. Survey Bull. 860 , pp. 31.-S0, 1936. 


\section{DIAGRAMS OF THE INTERTONGUING RELATIONS}

The present paper deals chiefly with the beds in the upper: part of the Mancos shale and the lower part of the Mesaverde formation. The character of each unit is described as it changes laterally from west to east. This is the general direction in which the rocks change from predominantly continental to predominantly marine types; correspondingly, it is the direction in which the Mesaverde grows thinner and the Mancos thicker by intertonguing and lithologic change. For convenjence, the succession and general relations of the members and tongues are shown in a simple diagram (fig. 22). these sections are shown by vertical lines and corresponding numbers; each line is drawn so as to indicate the stratigraphic range included in the measured section.

\section{MANCOS SHALE \\ NAME AND TYPE LOCALITY}

The name Mancos shale was given by Cross ${ }^{12}$ to the thick body of shale in the Mancos Valley near the town of Mancos, Colo. In a subsequent report Cross ${ }^{13}$ wrote:

It is an almost homogeneous body of soft, dark gray or nearly black, carbonaceous clay shale. *** The Mancos is therefore a lithologic unit which it is necessary to recognize in the mapping of this region. It is limited below by the Dakota sandstone and above by the lowest sandstone of the Mesaverde forma-

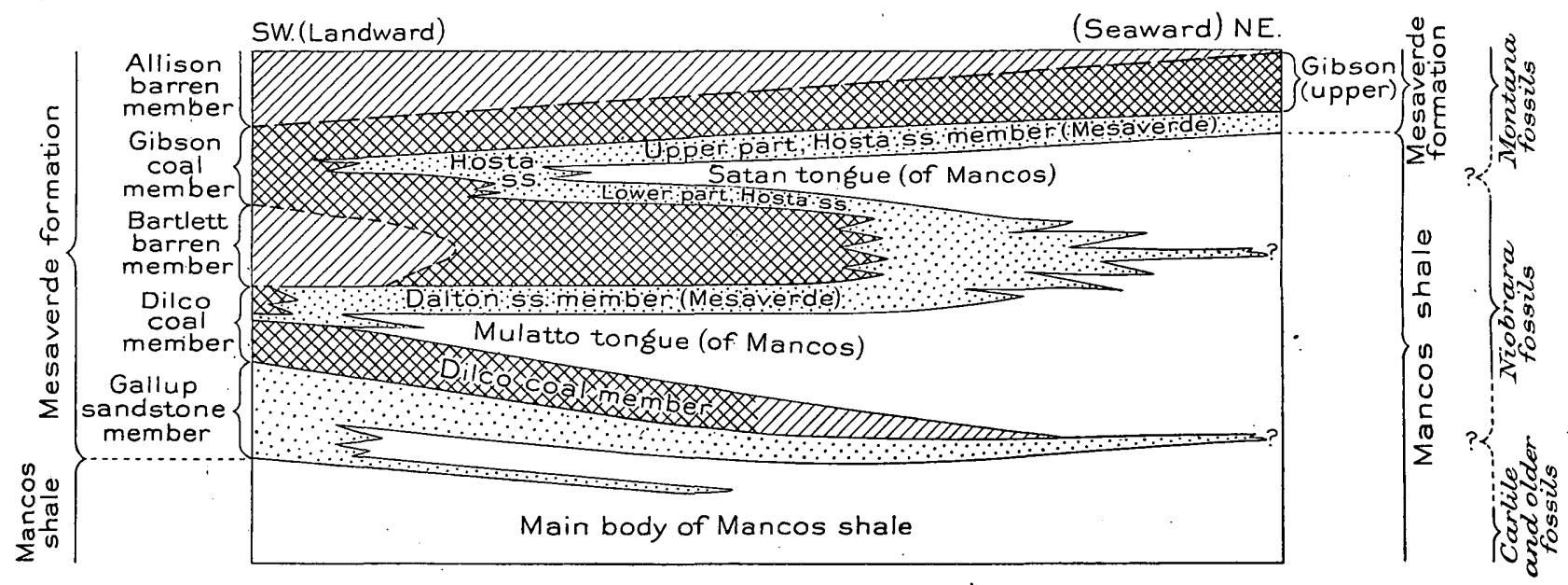

FIgure 22.- Simple diagram showing the landward-seaward variations and relations of the tongues and members of the Mancos shale and the Mesaverde formation.

Details of the vertical and lateral changes in lithologic character of the formations and their members, essential to the later discussion of shifting strand lines and the methods of deposition, are illustrated by a threedimensional correlation diagram (pl. 26). The tops of the cross-sections or walls in the diagram represent the lines $\mathrm{AB}, \mathrm{BC}$, etc., shown on the inset map, and are drawn in true horizontal relation to each other-that is, the angle between any two top lines is the same as on the map and in nature and is not distorted by perspective. All points along the tops of the walls are therefore in true geographic relation to each other. The walls below these top lines are constructed as a continuous 1,800 foot stratigraphic cross-section. The illusion of three dimensions in perspective is heightened by the distortion of the patterns in all walls other than the one that extends east and west (BC). However, there is no foreshortening, and the vertical scale is the same throughout. As measured parallel to the sides of the paper, the walls are of identical height at all points, and therefore all vertical sections can be directly scaled and compared.

The localities of the measured sections used in constructing the diagram are shown on the inset map by short lines and numbers. As projected on the walls, tion of alternating sandstones and shales. $* * *$ This lithologic unit embraces the Colorado group and a part of the Pierre division of the Montana group.

Thus the differentiation of the Mancos from underlying and overlying beds was based on their lithologic character, without reference to their marine or continental origin and with only incidental reference to their age.

\section{RELATION TO ADJACENT FORMATIONS}

In northwestern New Mexico the Mancos shale rests conformably upon a sandstone unit known as the Dakota (?) sandstone, the basal formation of the Upper Cretaceous series in the region. At many places the contact is transitional and no sharp plane of separation can be chosen. Locally the Dakota (?) sandstone is absent and the Mancos rests directly and unconformably upon older rocks.

The upper limit of the Mancos shale-its boundary with the Mesaverde formation-is more complex, and its changes of stratigraphic position are of considerable magnitude. From west to east across the southern

12 Cross, Whitman, U. S. Geol: Survey Geol. Atlas, Telluride folio (No. 57), p. 4, 1899.

${ }^{13}$ Cross, Whitman, U. S. Geol. Survey Geol. Atlas, La Plata folio (No. $60)$, p. 4,1899 . 
part of the basin, the Mancos-Mesaverde boundary rises stratigraphically a thousand feet or more by a process of intertonguing in which rocks of the Mesaverde type change gradually into marine shale of the Mancos.

\section{CHARACTER AND VARTATIONS OF THE MANCOS}

\section{MAIN BODY OF MANCOS SHALE}

The upper limit of the Mancos shale in the southwestern part of the San Juan Basin, near Gallup, has been placed "14 "at the bottom of the massive sandstone that forms the crest of the west ridge of the Hogback. Thus limited, the formation consists mainly of darkgray, somewhat sindy marine shale." The upper boundary in this locality is shown in plate $27, B$.

The following section of the Mancos was measured near the north end of the Hogback, where the formation is 725 feet thick:

Section of Mancos shale near north end of the Hogback, in sec. I, I'. 15 N., R. 18 W. (approximate location)

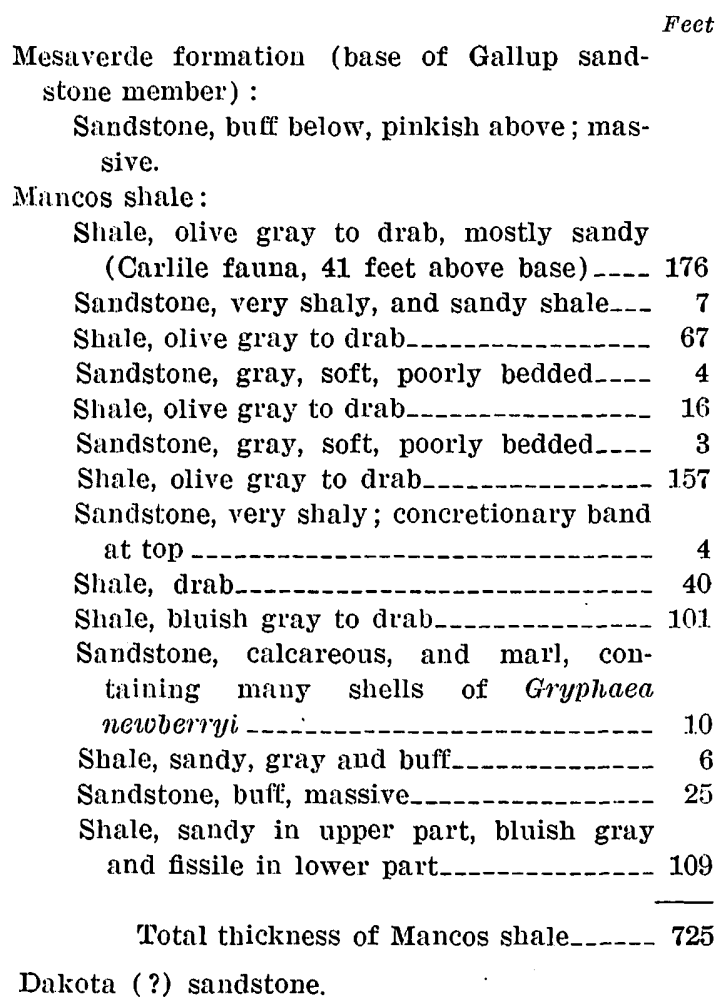

The beds in that portion of the foregoing section from the top of the Gryphaea newberryi zone up to and including the basal sandstone of the Mesaverde are shown in plate $27, A$.

The location of the section is approximately at point A, in plate 26. At this locality the Mancos has its minimum thickness in the San Juan basin; and, correspondingly, at this place the Mancos-Mesaverde boundary is

14 Sears, J. D., Geology and coal resources of the Gallup-Zuni Basin, N. Mex. : U. S. Geol. Survey Bull 767. p. 1.4, 1925. at its lowest or oldest stratigraphic position. A Carlile (late Benton) fauna was found 590 feet above the base of the section, so, even if the uppermost 135 feet of the shale (in which no fossils were found) is of Niobrara rather than of Carlile age, the Mancos in this vicinity represents only a part of the Colorado group, and the Mancos-Mesaverde contact here is much older than had hitherto been supposed. In contrast, at its type locality in southwestern Colorado the Mancos shale represents all of Colorado time and the earlier part of Montana time.

At point $\mathrm{A}$ the Gallup sandstone member (basal Mesaverde), which lies above the Mancos, consists of three massive sandstones with intervening clay and coal beds. Toward the northeast the lowest sandstone splits into two tongues, the upper of which, together with the everlying clay zone and a part of the middle sandstone, grades laterally into typical marine shale. As a consequence, in the vicinity of point $B$ the main body of Mancos shale is overlain by a massive and thin-bedded sandstone 53 feet thick, followed by 116 feet of sandy shale mostly of typical Mancos appearance, up to a massive cliff-forming sandstone representing the middle and upper sandstones of the Gallup. (See pl. $28, B$.) The 53-foot sandstone, known to be a tongue of the lowest sandstone of the Gallup, is at this point merely a bench-forming sandstone in the Mancos; eastward it becomes increasingly shaly, and finally it is completely replaced by shale so that there is a continuous shale sequence beneath the upper sandstone of the Gallup. Hence the upper shale in the vicinity of point $\mathrm{B}$ is actually the beginning of a tongue of the Mancos, and in effect the Mancos-Mesaverde boundary is about 170 feet higher stratigraphically there than near point A.

The lithologic change just described, reflecting a change from landward to seaward conditions of deposition, is most rapid in a northeasterly direction, which therefore is at right angles to the ancient shore line:

In marked contrast, the Gallup and uppermost Mancos beds show a notable uniformity as their outcrops swing to the east and southeast and approach.more c. Josely the trend of the old shore line. In the 55 miles from point $B$ eastward to $C$ and thence southeastward to $\mathrm{D}$, and also in the outcrops along the line GH, there is no material change in the stratigraphic position of the Mancos-Mesaverde boundary or in the character of the adjacent beds. Indeed, the only significant variation is the presence or absence of the two tongues of the lowest sandstone of the Gallup.

As the outcrops swing once more toward the northeast the seaward change of the beds resumes, though at a. much slower rate. The first effect is an abrupt vanishing of the sandstone tongues of the Gallup from the upper part of the Mancos. Thereafter, for a long distance northeastward along the lines DEF, GF, and 
IJ, the Mancos-Mesaverde contact remains at the base of the restricted Gallup sandstone member, but is thought to rise slowly by gradation of the basal beds of the Gallup into marine shale. Finally, near points $\mathbf{F}$ and $J$, the Gallup sandstone thins out and the underlying Mancos unites with an overlying shale of approximately equal thickness to form a continuous shale body. Expanded in this way to about 2,000 feet, the Mancos continues to the north beyond the field of this paper.

The overlying shale thus added to the Mancos is itself a union and expansion of two shale tongues, the Mulatto and Satan tongues (see pl. 26), which wedge into the Mesaverde rocks toward the south and southwest.

\section{MULATTO TONGUE}

The landward edge of the lower tongue was seen only near point B. Where section 5 (see pl. 26) was measured this tongue appears in the lower part of the Mesaverde as two zones of sandy shale and thin sandstones separated by more than 70 feet of generally massive sandstone. The lower zone is about 20 feet thick, and the upper zone about 45 feet. The marine origin of the shale is shown by its lithology and by a few marine fossils of Niobrara age found in the lower zone. Toward the east the intervening sandstone rapidly loses its massive character and thins out, and at section 7 the shale tongue formed by the union of the two zones is nearly 200 feet thick. From point C southeastward to $\mathrm{D}$ the thickening of the shale continues, as that direction has a slight seaward component. At section 9 the shale is 237 feet thick, at section 14 it is 260 feet (see pl. $28, A$ ), and at section 18 it is 375 feet thick, including a prominent 50 -foot sandstone lens in its upper part. Near this last-named locality excellent exposures of the shale are found at the mouth of Canyon Mulatto. From these exposures the unit has been named ${ }^{15}$ the Mulatto tongue of the Mancos shale.

Northeastward from point D the Mulatto tongue soon passes under cover. However, in a well drilled in the Miguel Creek dome, the log of which forms the lower part of section 21, the Mulatto is about 400 feet thick. Eastward from point $\mathrm{E}$ the Mulatto thickens more rapidly. Finally, northeast of point $\mathrm{F}$, the overlying and underlying sandstones die out and the Mulatto tongue becomes a part of the expanded Mancos shale.

Southwest and southeast of Mount Taylor, along lines $\mathrm{GH}$ and $\mathrm{KL}$, the Mulatto tongue is well developed. Its appearance, thickness, and relations to adjacent beds are comparable to those seen in the outcrops along line $\mathrm{CD}$, and there is no trace of its landward edge such as that found near point $B$. Toward the northeast, along lines GF and IJ, the Mulatto tongue thickens at the expense of the underlying and overlying beds by small-

\footnotetext{
${ }^{15}$ Hunt, C. B., The Mount Taylor coal field : U. S. Geol. Survey Bull. 860, p. 44,1936 .
}

scale intertonguing, and merges with and becomes part of the expanded Mancos shale at the northeast corner of the field.

\section{SATAN TONGUE}

The upper tongue of the Mancos does not extend as far westward and southwestward as the Mulatto tongue, therefore it is not seen in the outcrops along lines ABCD, GH, and KL. At many localities (for examples, see the spur walls $a^{\prime}, b^{\prime}, c^{\prime}$, and $d^{\prime}$ of wall $\mathrm{CD}$, and walls DE, GF, and IJ in pl. 26), it begins as one or more thin wedges of marine shale splitting a thick cliff-forming sandstone in the midst of the Mesaverde formation about 500 feet above the top of the Mulatto. At each place, the shale tongue thickens rapidly toward the northeast, chiefly by the adjacent sandstone beds grading northeastward into shale, and within a few miles it reaches a thickness of 150 feet or more.

The beginning and growth of the shale tongue and its relation to the sandstone that it splits are well shown by the exposures in Satan Pass (see pl. 28, $C$ ), along the road from Thoreau to Crown Point. The unit has therefore been named ${ }^{16}$ the Satan tongue of the Mancos shale.

In the western part of the field the Satan tongue passes rapidly under cover of younger beds toward the north, and hence only its more landward part can be observed. In the eastern part of the field it is exposed over a much wider area. Northeastward along the lines DEF, GF, and IJ it thickens to more than 300 feet. This increase seems to be chiefly at the expense of the underlying sandstone, from which successive wedges separate and pass laterally into marine shale. The upper boundary of the Satan is more regular, though the contact with the overlying massive sandstone is thought to rise very gradually across time planes toward the northeast.

Beyond points $\mathbf{F}$ and $J$ the Satan tongue merges with the expanded Mancos shale, and the overlying sandstone becomes the basal unit of the restricted Mesaverde formation. Thus the Mancos-Mesaverde boundary rises stratigraphically about 1,200 feet from point $\mathbf{A}$ to point F, 100 miles to the east. That distance, however, is measured in a direction oblique to the trend of the ancient shores; toward the northeast-that is, directly seaward-this stratigraphic rise of 1,200 feet takes place within a distance of only 60 miles.

\section{MESAVERDE FORMATION}

NAME AND TYPE LOCALITY

The term "Mesa Verde Group" was used by Holmes ${ }^{17}$ to describe a series of rocks 1,100 to 1,200 feet thick,

${ }^{10}$ Sears, J. D., The coal field from Gallup eastward toward Mount Taylor: U. S. Geol. Survey Bull. 860, p. 14, 1934.

17 Holmes, W. H., Geological report on the San Juan district: U. S. Geol, and Geog. Survey Terr. Ninth Ann. Rept., pp. 237-276, 1875. 
lying above "the great series of Middle Cretaceous shales" (Mancos shale) and below the "Sand Shale Group" (Lewis shale). The name was derived from the Mesa Verde, in southwestern Colorado, where excellent exposures are widespread. Three divisions of the group were described by Holmes as the "Upper Escarpment" and "Lower Escarpment" sandstones and the "Middle Coal Group."

Fossil evidence reported by Cross ${ }^{18}$ indicates that the Mesaverde in southwestern Colorado is of middle Pierre (Montana) age.

In a report on coal deposits near Mancos, Colo., Collier ${ }^{10}$ named the three divisions of the Mesaverde group, in ascending order, the Point Lookout sandstone, 250 to 300 feet thick; the Menefee formation, consisting of 400 feet of sandstone, shale, and coal beds; and the Cliff House sandstone, several hundred feet thick.

MESAVERDE NEAR GALLUP, N. MEX.

In the Gallup coal district, at the southwest corner of the San Juan Basin, the Mesaverde was originally at least twice as thick as at the type locality in southwestern Colorado. 'The upper part has been removed by erosion but can be seen some miles to the northeast. The part that remains comprises 1,800 feet of alternating sandstone, clay, and coal beds. The three beds of sandstone near the base are massive and persistent; all the other's are irregular and nonpersistent, so that stratigraphic sections vary greatly in detail from place to place. The coal beds range in thickness from a few inches to 10 feet, and the intervals between them differ greatly from point to point.

Divisions of the Mesaverde formation in the Gallup-Zuni Basin, N. Mex.

\begin{tabular}{|c|c|c|}
\hline Memiber & $\begin{array}{c}\text { Thick- } \\
\text { ness }\end{array}$ & Character \\
\hline Allison barren momber.. & $\begin{array}{l}\text { Feet } \\
800\end{array}$ & Lenticular sandstones, light-colored clay, \\
\hline & & $\begin{array}{l}\text { and thin irregular coal beds, but none of } \\
\text { commercial importance. Top of member } \\
\text { croded; total thickness undetermined. }\end{array}$ \\
\hline Cibson coal member......... & $150-175$ & Valuable coal beds, lenticular sandstones, \\
\hline Bartlett barren momber...... & $330-400$ & $\begin{array}{l}\text { Lenticular sandstones, light-colored clay, } \\
\text { and thin, irregular coal beds, but none of }\end{array}$ \\
\hline Dilco coal momber & $240-300$ & Valuable coal beds, lenticular sandstones, \\
\hline Callup saudstone member.... & $180-250$ & $\begin{array}{l}3 \text { thick persistent massive sandstones; inter- } \\
\text { bedded clay and coal beds, the upper of } \\
\text { which are locally of commercial im- } \\
\text { portance. }\end{array}$ \\
\hline
\end{tabular}

The Mesaverde in the Gallup district has been described ${ }^{20}$ as a single formation rather than a group and has been divided into five members, partly because of the lithologic differences and partly for convenience in de-

\footnotetext{
${ }^{18}$ Cross, Whitman, U. S. Geol. Survey Geol. Atlas, La Plata folio (No. 60), p. 5, 1899 .

to Collier, A. J., Coal south of Mancos, Montezuma County; Colo: U. S. Geol. Survey Bull. 691, pp. 296-297, 1919.

${ }^{2}$ Sears, J. D., Geology and coal resources of the Gallup-Zuni Basin, N. Mex. : U. S. Geol. Survey Bull. 767, pp. 15L-18, 1925,
}

scription. 'The basal unit, about 200 feet thick, consisting of the three persistent sandstones and the interbedded shale and coal, is readily separable from the rest of the formation. (See pl. 27, B.) The overlying 1,600 feet of irregular sandstone, clay, and coal beds has been divided on the basis of the presence or absence of valuable coals. The five members, in order from top to bottom, are briefly described in the preceding table.

\section{MESA VERDE IN SOUTHERN SAN JUAN BASIN}

The area covered by the present paper extends from the Gallup district eastward across the southern part of the San Juan Basin and beyond it into the zone of block faulting southeast of the basin. Within this area the character of the Mesaverde formation changes notably toward the east and northeast. The members seen in the Gallup district are modified, new members appear in the section, and finally all the lower 1,200 feet of Mesaverde rocks intertongue with and grade laterally into marine shale of the Mancos. The character and lateral changes of the several members, in ascending order, are described in the following pages.

\section{GALLUP SANDSTONE MEMBER}

The basal sandstone member of the Mesaverde, comparatively uniform in character and thickness throughout the Gallup-Zuni Basin, changes rapidly toward the northeast from the north end of the Hogback (along line $\mathrm{AB}$, in pl. 26), as outlined in the description of the main body of the Mancos shale. With these changes the appearance of the Gallup sandstone member is as shown in plate $28, B$. In section 5 the Gallup consists of a lower bench-forming sandstone 53 feet thick, in thin and thick layers, representing the basal part of the lower sandstone of the Hogback section; and an upper sandstone unit 152 feet thick, consisting of thick- and thin-bedded sandstones with two thin partings of clay and impure coal and representing the combined middle and upper sandstone of the Hogback section. The two sandstone units are separated by 116 feet of shale, in small part carbonaceous but mostly of marine appearance, representing a tongue of the Mancos.

Eastward from the point where section 5 was measured, the lower bench-forming sandstone is exposed almost continuously to a point west of section 9 , where it is seen to thin out within a short distance by lateral transition to shale in the face of a promontory south of Hosta Butte. Near section 7 a second bench-forming sandstone appears above the first, and also continues southeastward to the promontory near Hosta Butte, where it likewise thins out. Within an equally short distance the upper bench reappears and continues far southeastward to point $\mathrm{D}$. In the cross-section diagram and on a map of the area the upper bench sandstone has the appearance of disconnected lenses. However, 
this sandstone is believed to represent the layer that splits from the top of the lower sandstone of the Gallup between points $\mathbf{A}$ and B. If so, the gaps in its outcrop and the resultant lens-like appearance are caused chiefly by the irregular shape of the line of outcrop, which cuts back and forth across the seaward feather edge of the sandstone. Under this interpretation both the upper and lower bench-forming sandstones formerly were connected landward (southwestward) with the lower sandstone of the Gallup, and hence represent tongues of that sandstone between small tongues of the Mancos shale. This interpretation is strengthened by exposures near section 14 . Here only the upper bench sandstone is present; it is 22 feet thick and is overlain by 118 feet of gray sandy marine shale (of the Mancos) up to the main sandstone of the Gallup. Within a short distance to the south, however, the lower bench sandstone appears, and within 2 miles both bench sandstones are more than 50 feet thick.

An outcrop of what are believed to be the same two bench sandstones was found southwest of Mount Taylor, near Grants (sec. 32, wall GH). Because of poor exposures these sandstones could not be traced satisfactorily toward the southeast, but on the basis of interval below the main Gallup the lower is thought to be the one that continues to sections 30,29 , and 28 .

Northeastward from point $\mathrm{D}$. and from the vicinity of section 28 there is no further trace of either of these sandstone tongues of the Gallup in the Mancos shale.

With its lower part lost by lateral transition into marine shale, the Gallup sandstone member throughout most of the area covered by this paper consists only of the upper beds included in the full member at its type locality. At section 5, as already described, the upper part consists of 152 feet of sandstone with two thin partings of shale and bony coal. The member thus restricted continues far to the east and southeast. Locally it shows two or more distinct sandstones with interbedded clay and some coal, but over the greater part of the area it consists of essentially continuous sandstone ranging in thickness from 60 to 150 feet. Locally (for example, in the area between sections 14 and 18) the upper part of the sandstone weathers into rounded forms whose surfaces are conspicuously broken by polygonal jointing. (See pl. $29, A$ and $B$.)

After relative uniformity over a wide area, the member shows a final seaward change in the northeast corner of the field. For some miles, because of the dying out of the overlying continental beds and the growth of the Mulatto tongue of the Mancos shale, the Gallup continues merely as a thin sandstone in the midst of a thick body of marine shale; this sandstone becomes gradually thinner and more shaly northeastward, and finally is an inconspicuous sandy zone in the midst of the Mancos shale. (See walls EF, GF, and $\mathrm{IJ}$.
In the valley of the Rio Puerco the single, relatively thin sandstone representing the Gallup was found to be the "Punta de la Mesa sandstone" of Herrick and Johnson, ${ }^{21}$ who considered it to be of Fox Hills age. Lee ${ }^{22}$ at first regarded the "Punta de la Mesa" as the base of the Mesaverde formation in that vicinity, including in that formation the overlying somewhat sandy shales herein described as the Mulatto and Satan tongues of the Mancos. Subsequently, because investigations had shown the "Punta de la: Mesa" to be hundreds of feet below the top of the Mancos as developed farther north, Lee ${ }^{23}$ came to regard it as a member of the Mancos, although he wrote: "In the Rio Puerco field it is not possible, without further investigation, to draw a definite line between Mancos and Mesaverde." Lee's reconnaissance had not made clear the intertonguing relationship; he thus grouped as part of a single formation a thousand feet of rocks that are actually the intertonguing parts of two formations. Because of this grouping and because the "Punta de la Mesa" was described only in a very limited area and its outcrops are not shown on any map, that name is here replaced by the more widely used name, Gallup sandstone member of the Mesaverde.

\section{DILCO COAL MEMBER}

In the eastern part of the Gallup coal district the Dilco coal member comprises 250 to 300 feet of irregular sandstones, light-colored claỳ, and nine lenticular coal beds, some of which locally reach a thickness of 5 feet or more.

Northward along the Hogback from the vicinity of the old Heaton mine (point A, pl. 26) the coals in the upper half of the Dilco grade within a short distance into carbonaceous shale and clay; the Black Diamond bed, which is the most persistent and valuable coal of the member in the Gallup district, is the last to disappear. Just below the Black Diamond coal, a sandstone, which is thin but somewhat persistent in the Gallup district, thickens rapidly, and new sandstones appear in the zone above. Within a distance of about 2 miles the upper half of the Dilco is replaced by a body of almost continuous sandstone about 180 feet thick. This sandy zone is shown in section 2 , measured where the Hogback ends by a swing of the rock beds from a steep westerly to a gentle northerly dip.

The sandstone unit thus appearing in the section is dèscribed on page 113 as the Dalton sandstone member of the Mesaverde.

From the north end of the Hogback eastward along the margin of the basin the lower half of the Dilco con-

${ }^{21}$ Herrick, C. L., and Johnson, D. W., The geology of the Albuquerque sheet: New Mexico Univ. Hadley Lab. Bull., vol. 2, pt. 1, p. 15, 1900.

${ }^{22}$ Lee, W. T., Stratigraphy of the coal fields of nortbern central New Mexico:- Geol. Soc. America Bull., vol. 23, pp. 622-625, 1912.

${ }^{23}$ Lee, W. T., Geology and paleontology of the Raton Mesa and other regions in Colorado and New Mexico: U. S. Geol. Survey Prof. Paper 101, pp. 174, 194-197, 1917. 
tinues with only gradual change. This restricted unit forms the Dilco coal member as described in the present paper. In the west half of the area (see walls ABCD and $\mathrm{GH}, \mathrm{pl} .26$ ) the member ranges in thickness from 120 to 200 feet, and includes several lenticular coals which only locally are more than 3 feet thick. Northeastward from points $D$ and $G$ the coal beds die out, but the clays and irregular sandstones maintain their continental aspect. The member gradually thins, however, chiefly by gradation of the uppermost beds to marine shale, and in the northeast corner of the area the Mulatto tongue of the Mancos shale, thus expanded, rests directly on the thin Gallup sandstone (secs. 22, 23 , and 45).

In the central part of the area a conspicuous bed of sandstone that attains a maximum thickness of 75 feet was found between the typical beds of the Dilco coal member and the overlying Mulatto tongue of the Mancos shale. Probably its original extent was about that of the stippled zone in the inset map, plate 26 . Because of its limited extent the sandstone has not been given a formal stratigraphic name, but for convenience it will be referred to in this paper by its field designation, the "stray sandstone." It is shown as a separate sandstone in the correlation diagram (in walls CD and GH, in the spur wall $e^{\prime}$, and northeastward in the wall GF as far as sec. 28), because at places it forms an unbroken cliff-forming unit, apparently unrelated to the overlying and underlying beds. However, it may well be that the greater part of the "stray" belongs to the Dilco, and that its uppermost part-a thin but wellmarked sandy layer carrying rounded, generally elongate pebbles as much as 3 inches in length-represents local deposition of coarse material during the early part of the marine transgression that resulted in the Mulatto tongue of the Mancos shale. This pebbly layer is found in much of the area represented in wall CD by the lens between sections 9 and 14. Locally it is separated from the main body of the "stray sandstone" by 3 to 25 feet of clay that includes some black carbonaceous shale and streaks of coal.

In the smaller lens 4 miles to the southeast, the "stray" includes several conspicuous bodies of sandy marl composed almost wholly of Ostrea solemiscus. (See pl. 30, A.) Locally this unbedded marl shows striking lateral intergrowth with nonfossiliferous well-marked layers of the "stray sandstone." (See pl. 30, $B$ and $C$.) Probably there were estuarine conditions that favored the growth of extensive colonies or reefs of these oysters despite the rapid deposition of sand virtually surrounding them.

\section{DALTON SANDSTONE MEMBER}

As already noted, the upper half of the Dilco coal member near the north end of the Hogback is replaced within a short distance by a sandstone body which at section 2 is about 180 feet thick and includes only two thin beds of softer sandstone and sandy shale.

A few miles farther east, at section 5, the unit is divided into two distinct cliff-forming sandstones, the upper of which is 96 feet thick and the lower 72 feet thick; these are separated by 44 feet of shale. This intervening shale and about 20 feet of the shale immediately beneath the lower sandstone are fissile and of Mancos type. In the lower zone of shale were found a few marine fossils of Niobrara age. These zones of shale are the landward end of the Mulatto tongue of Mancos shale.

East of section 6 the lower sandstone rapidly becomes thinner and more shaly and wedges out in the midst of shale of the Mulatto tongue, which rests directly on the Dilco coal member.

The upper sandstone continues far to the east, with a rather uniform thickness of about 100 feet. From its excellent exposures at Dalton Pass, where it supports the divide and forms a conspicuous bench in the canyon draining to the north, the unit has been named the Dalton sandstone member of the Mesaverde. ${ }^{24}$ In general the Dalton is a clean, white to buff massive sandstone, at places containing marine fossils of Niobrara age.

In the northeastern part of the area (between secs. 21 and 22 in wall DEF and between secs. 24 and 23 in wall GF), the base of the sandstone moves stratigraphically upward in a serrate pattern through the separation of small tongues that grade laterally into shale of the expanding Mulatto tongue. Simultaneously the overlying continental beds become increasingly sandy, and the sandstone above them loses its upper part by the separation of tongues that die out laterally into shale of the Satan tongue. By this process the 300 to 400 feet of Mesaverde rocks between the Mulatto and Satan tongues of the Mancos are, within a few miles, represented only by a single, relatively thin sandstone in the midst of a great body of marine shale. This sandstone becomes softer and thinner and, like the Gallup sandstone member, is a mere sandy zone in the midst of the Mancos shale near the northeast corner of the area. At that point the Mulatto and Satan tongues merge with the. lower shale to form an expanded Mancos about 2,000 feet thick.

This change in the Dalton and overlying beds is seen also, but less clearly, in the outcrops along the line IJ.

\section{BARTLETT BARREN MEMBER}

In the Gallup district the Bartlett barren member, 330 to 400 feet thick, is lithologically similar to the underlying Dilco and overlying Gibson coal members. It is differentiated from those units, however, because its few coal beds are less than 14 inches thick, except in

24 Sears, J. D., The coal field from Gallup eastward toward Mount Taylor: U. S. Geol. Survey Bull. 860, p. 17, 1934. (For location of Dalton Pass, see map, pl. 1.) 
small lenses, and are of no commercial importance. The member has relatively small extent in the area described in the present paper. For some miles eastward from the Hogback (wall ABC) it continues as a thick barren zone, its base resting either on the Dilco coal member or the Dalton sandstone member. However, beginning near section 6 and continuing far to the east and southeast, this zone includes more numerous and thicker coal beds. The Bartlett barren member is therefore considered as ending near section 6 by lateral gradation into coal-bearing rocks that are assigned to and hence expand the overlying coal member.

\section{GIBSON COAL MEMBER}

At the north end of the Hogback and for some miles to the east (wall $\mathrm{AB}$ ) the Gibson coal member comprises about 250 feet of clay, irregular sandstones, and coals. (See pl. 29, C.) Locally it contains nearly a dozen coal beds ranging in thickness from 14 inches to 12 feet. In the southeast part of the area (see secs. 31 and 49) the apparent equivalent of the Gibson member is considerably thicker, but exposures there are not very satisfactory.

A sandstone, wedging into the midst of the member near point $\mathrm{B}$, thickens greatly in short distances toward the north and east, attaining a thickness of 150 feet within a few miles. This sandstone, a separate member of the Mesaverde, divides the Gibson coal memker into two parts throughout most of the area covered by the present report. The upper part of the Gibson continues above the sandstone without material change to and beyond the northeast corner of the area and will not be described further.

The lower part of the Gibson coal member, expanded downward near section 6 by the inclusion of the zone that to the west forms the Bartlett member, continues eastward for several miles with a thickness of about 4.00 feet. Near section 7, at the south end of Dalton Pass, several wedges of sandstone that appear in its upper 100 feet thicken in short distances and coalesce with the overlying massive sandstone unit. From that vicinity the lower part of the Gibson continues as a coal-bearing zone far to the east and southeast (wall $\mathrm{CD}$ ), generally ranging in thickness from 275 to 300 feet. Its contact with the underlying Dalton sandstone is irregular at many places, and the lenticular sandstones near the base of the Gibson locally touch the Dalton and make it difficult to determine a consistent dividing line.

Northeastward from point D the lower part of the Gibson continues without change for a few miles. Farther along the line DE the zone is under cover of higher beds. It evidently undergoes a material change, however, for in a well drilled in the Miguel Creek dome (the log of which forms the lower part of sec. 21) the zone is represented chiefly by sandstones. The inferred manner in which the sandstones replace the clays and coal beds is indicated diagrammatically in the crosssection, plate 26. As already discussed in the description of the Dalton, these sandstones, together with the underlying Dalton and the sandstone above the lower: Gibson, unite to form a thick sandy zone, which in turn thins eastward and northeastward by gradation into the marine shale of the Mancos.

Similar changes of the lower part of the Gibson coal member: were observed along lines GF and IJ, where the unit grades northeastward into sandstones near section 24 and between sections 45 and 46 .

\section{HOSTA SANDSTONE MEMBER}

The sandstone that splits the Gibson coal member has been named ${ }^{25}$ the Hosta sandstone member of the Mesaverde, because it caps Hosta Butte, a prominent landmark in T. 16 N., R. 13 W.

The landward edge of the Hosta was observed only in the vicinity of point $B$, where it begins in the midst of the Gibson as two thin sandstones separated by a few feet of clay and coal. The two sandstones join within a short distance eastward, and thereafter the unit thickens rapidly. Near section 6 it is 150 feet thick, and near section 7 it increases to 200 feet or more by the addition of basal sandstone beds that are formed by lateral transition of the upper beds of the lower Gibson. (See fig. 23, left-hand part.) From the locality of section 7 the unit continues far to the east and southeast along line $\mathrm{CD}$ with rather uniform thickness and character. It consists almost wholly of sandstone, the upper part weathering into ledges and at places into beehive forms (see pl. 31, $C$ ), and the lower part being in general very massive and forming a great and nearly continuous rim or escarpment. Locally its contact with the underlying Gibson is somewhat irregular, and there are occasional thin clays and small coal lenses in the lower 25 or 50 feet of the sandstone.

In striking contrast to the uniformity of the Hosta along line CD, there is a marked and abrupt change northeastward from that line. Within a few miles the member splits into two distinct sandstone units, separated by the Satan tongue of the Mancos shale, which thickens toward the northeast. This splitting of the Hosta sandstone member is shown graphically in plate 26 (in spur walls $a^{\prime}, b^{\prime}, c^{\prime}$, and $d^{\prime}$ of wall $C D$, and in wall $\mathrm{DE}$ ); and the details of the transition near Dalton Pass are expressed in figure 23. The appearance of the upper and lower parts of the Hosta and the intervening Satan tongue where the splitting is complete is shown in plate $28, C$.

The landward edge of the Hosta cannot be recognized near Mount Taylor or in the southeastern part of the field. The Hosta is a thick, fully developed

${ }^{25}$ Sears, J. D., op. cit., p. 18. 


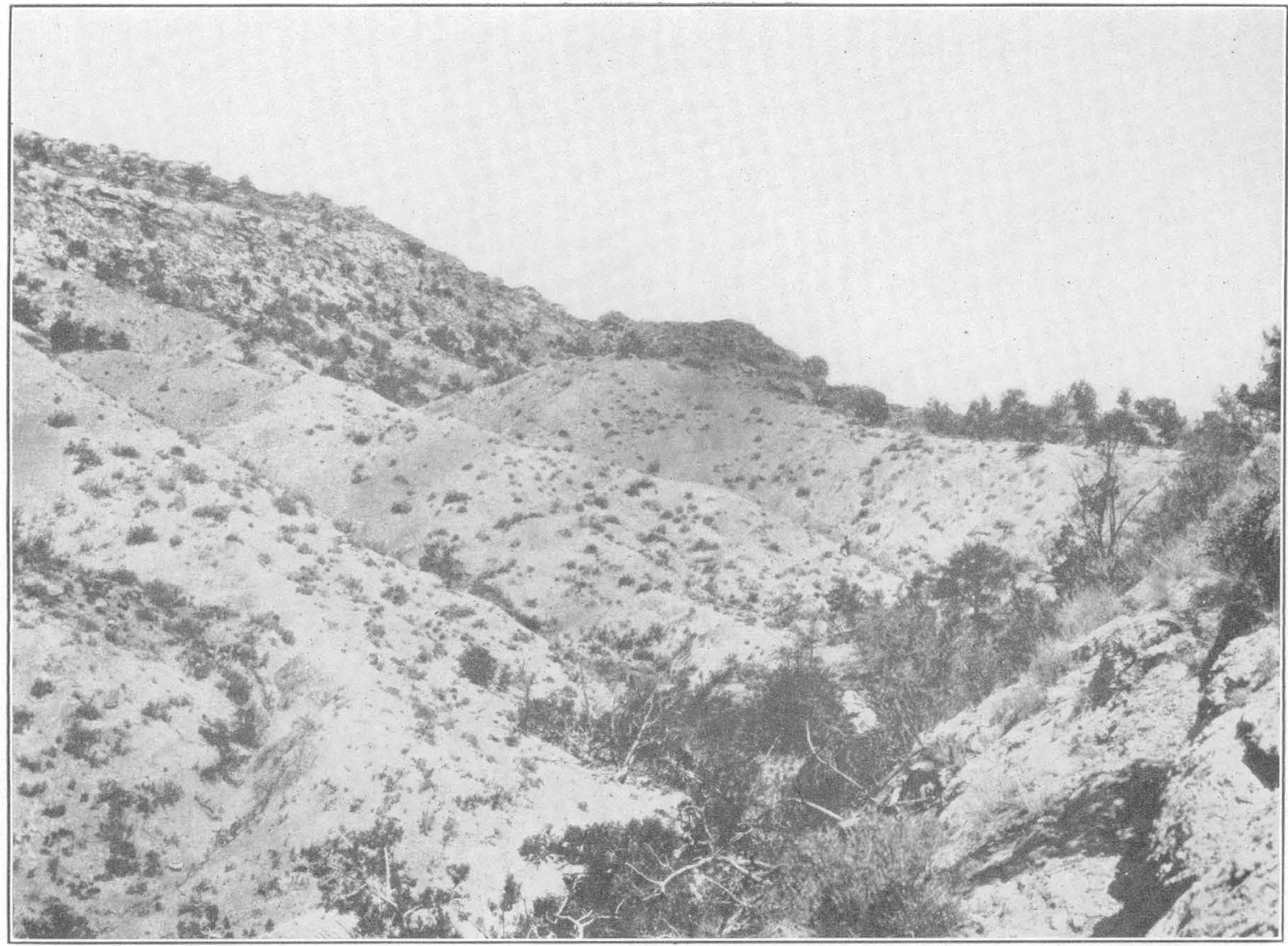

A. UPPER PART OF MANCOS SHALE AND BASAL SANDSTONES OF MESAVERDE FORMATION, NEAR NORTH END OF THE HOGBACK NORTHEAST OF GALLUP.

The top of the Gryphaea neuberryi zone is seen at the right.

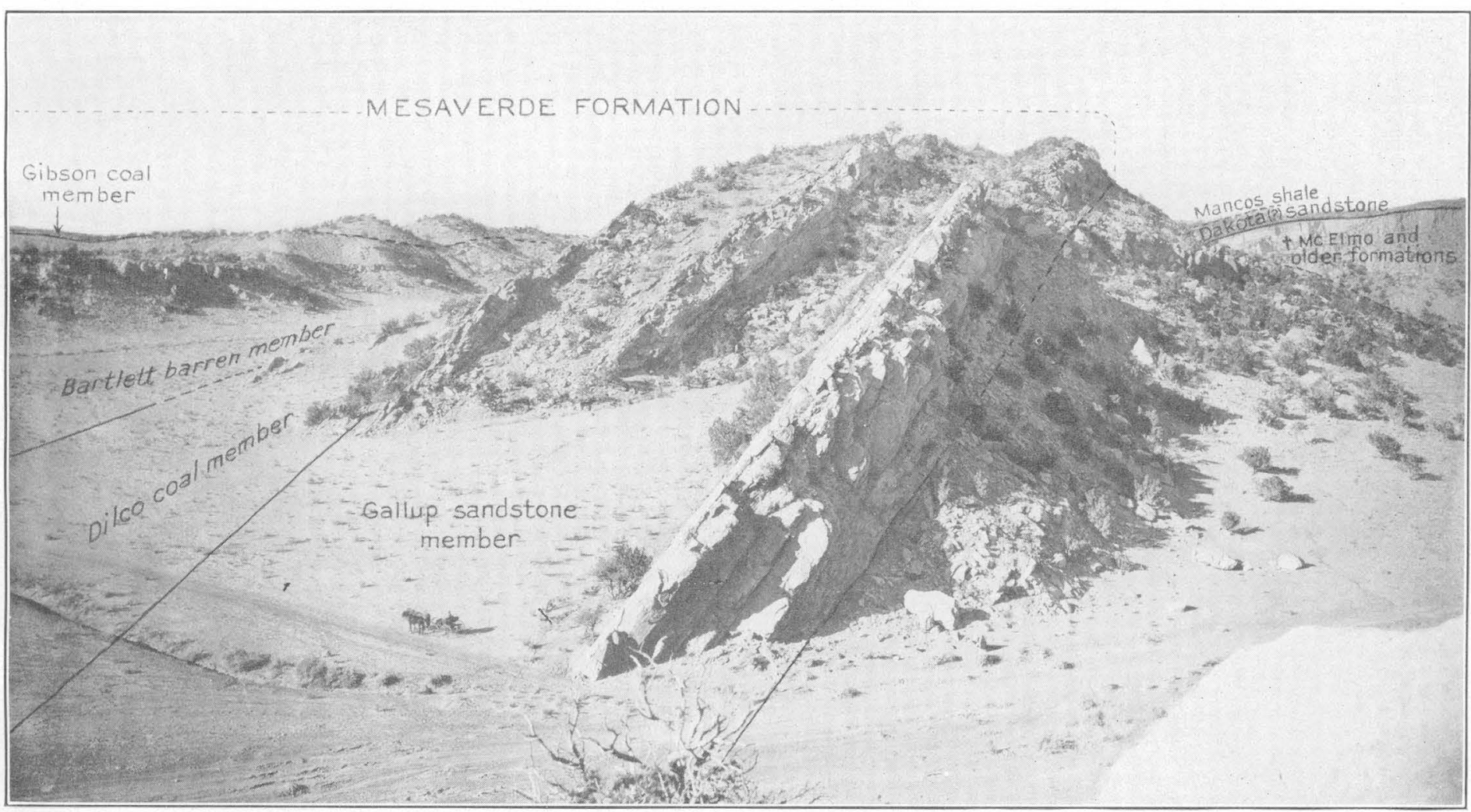

B. LOWER MEMBERS OF MESAVERDE FORMATION IN EASTERN PART OF GALLUP COAL DISTRICT, AS NAMED IN BULLETIN 767. View of the Hogback 21/2 miles northeast of Gallup. Photograph by N. H. Darton. 


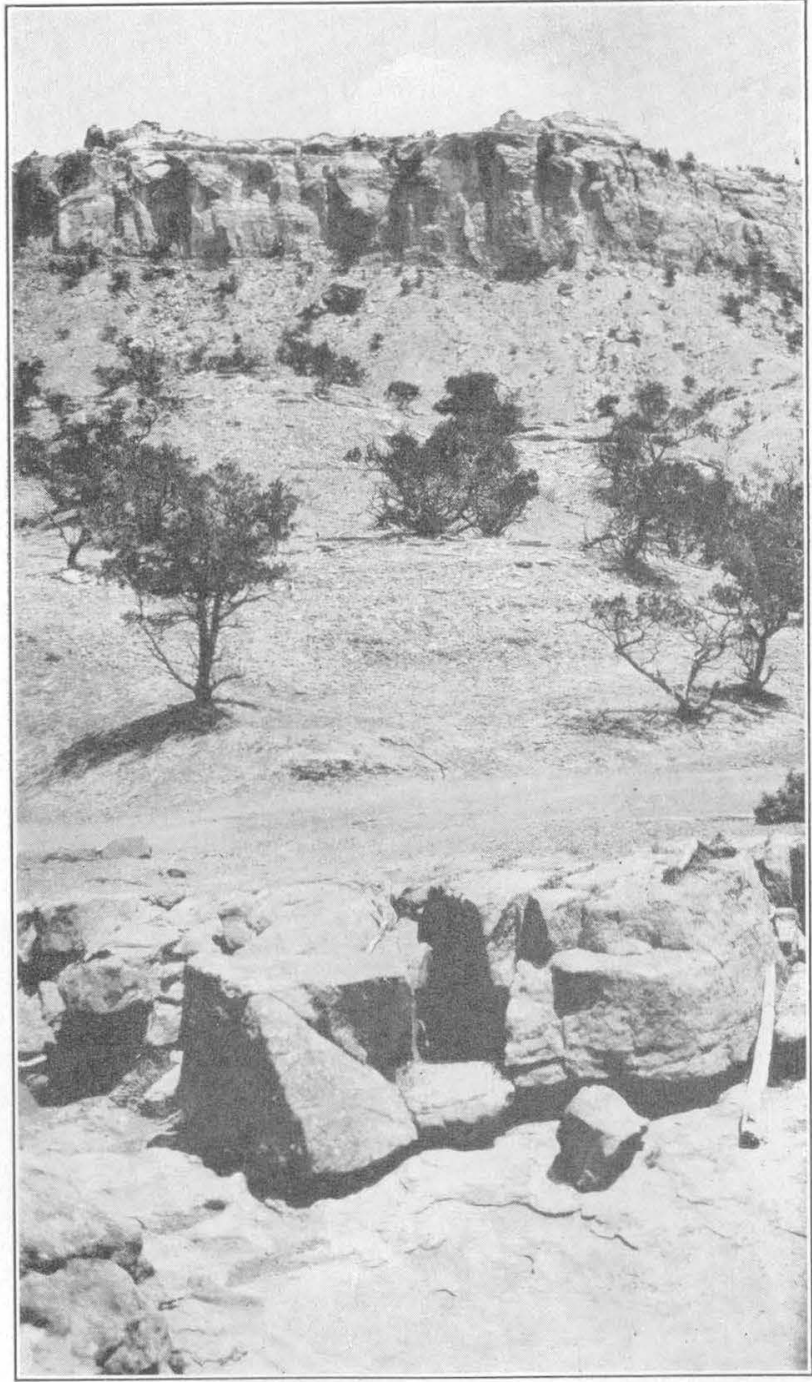

A. MULATTOTONGUE OF MANCOS SHALE OVERLAIN BY DALTON SANDSTONE MEMBER OF MESAVERDE FORMATION; IN FORE

View in sec. $30, T$. T. $15 \mathrm{~N} ., \mathrm{R} .10 \mathrm{~W}$. (about 2 miles west of the locality of sec.
14 in the diagram, pl, 26). At this locality the Mulatto is about 250 feet thick. Through the eombined effects of topographic soppe, dip of bed, thickness of the lower, rather sandy portion of the Mulatto, which extends partly hidden upper, less sandy portion of the Mulatto.

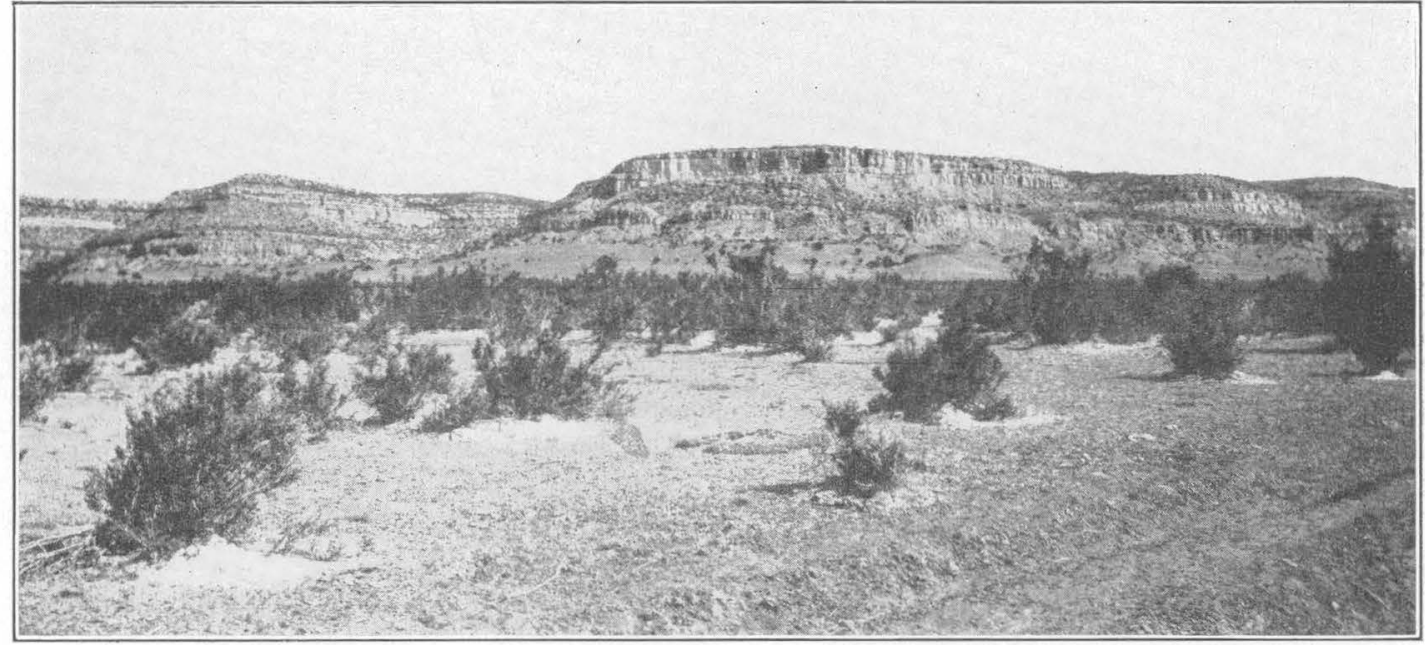

B. INTERTONGUING OF MANCOS SHALE AND GALLUP SANDSTONE MEMBER OF MESAVERDE FORMATION. Foreground and lower slope, main body of Mancos; bench, a sandstone wedge from the Gallup, thinning eastward (toward the right);
upper slope, a tongue of Mancos thinning westward; cliff, main body of Gallup sandstone member. (Between point $B$ and sec. 5 in the

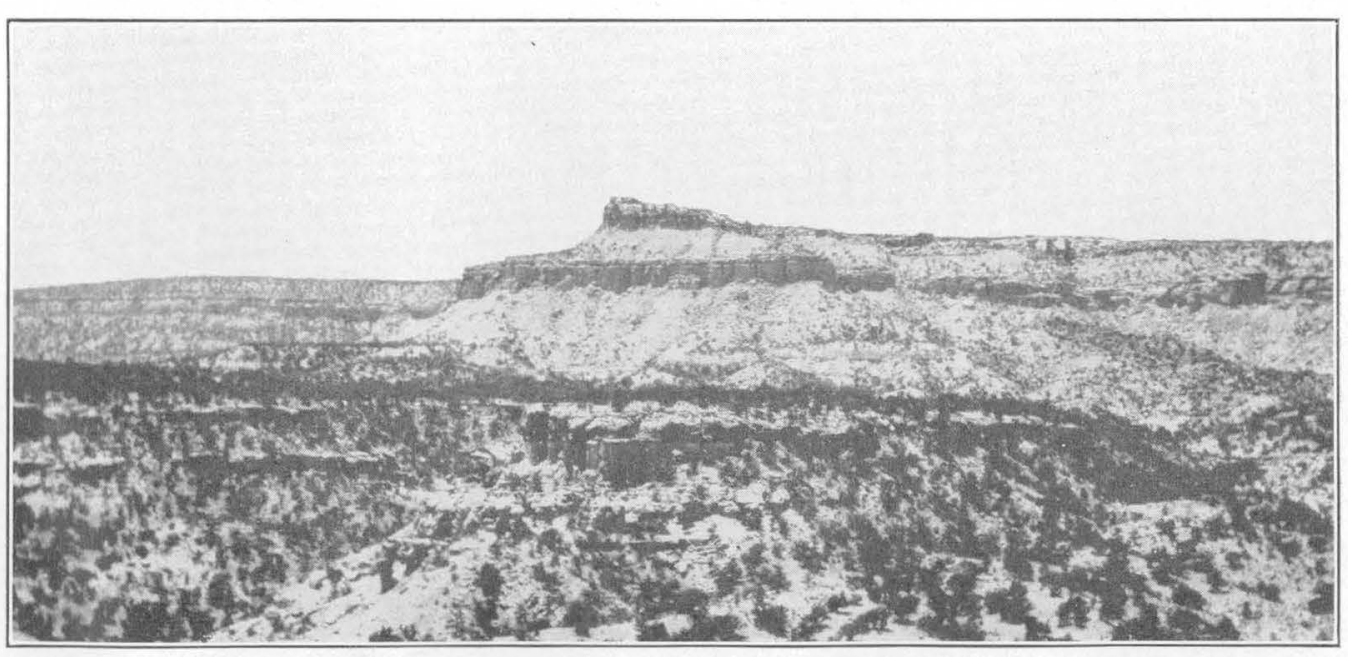

C. HOSTA SANDSTONE MEMBER OF MESAVERDE FORMATION SPLIT BY SATAN TONGUE OF MANCOS SHALE. Upper two ledges of sandstone are the Hosta; intervening shale is the Satan tongue; intermediate slope, lower part of Gibson coal member;
sandstones in foreground, the Daltoon sandstone member. View looking west at north end of Satan Pass, southeast of Crown Point (nea point $a^{\prime}$ on the spur from wall $\mathrm{CD}$ in the diagram, pl, 26). 


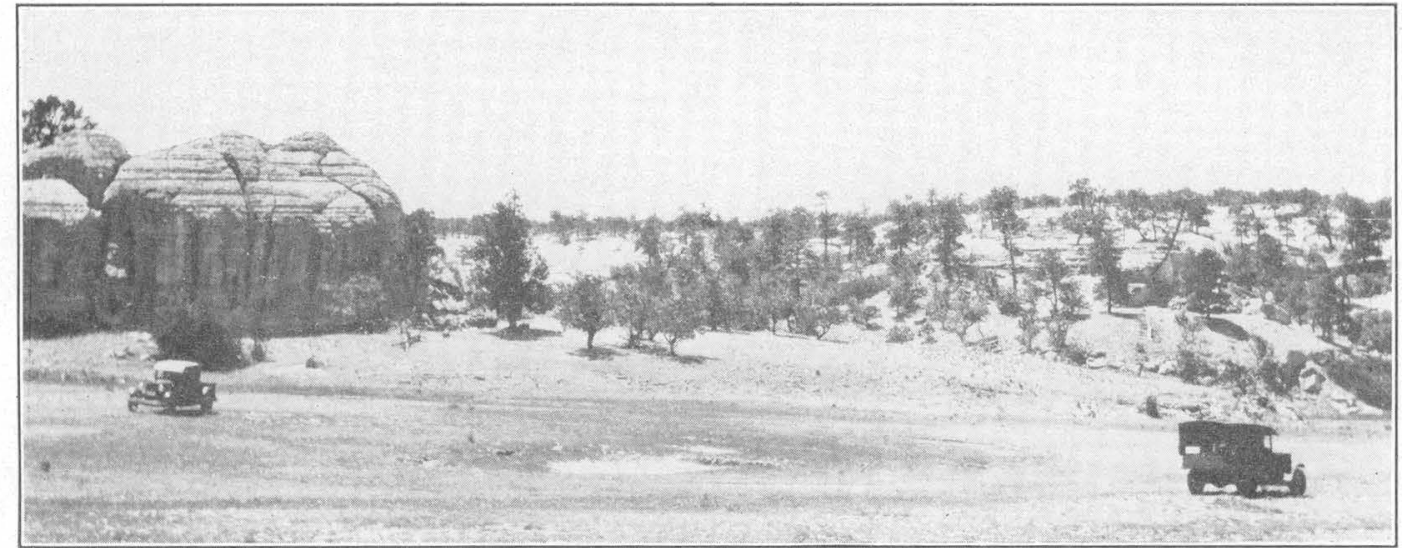

A. GALLUP SANDSTONE MEMBER OF MESAVERDE FORMATION, SHOWING MODE OF WEATHERING. Sec. 16, T. 14 N., R. 9 W.

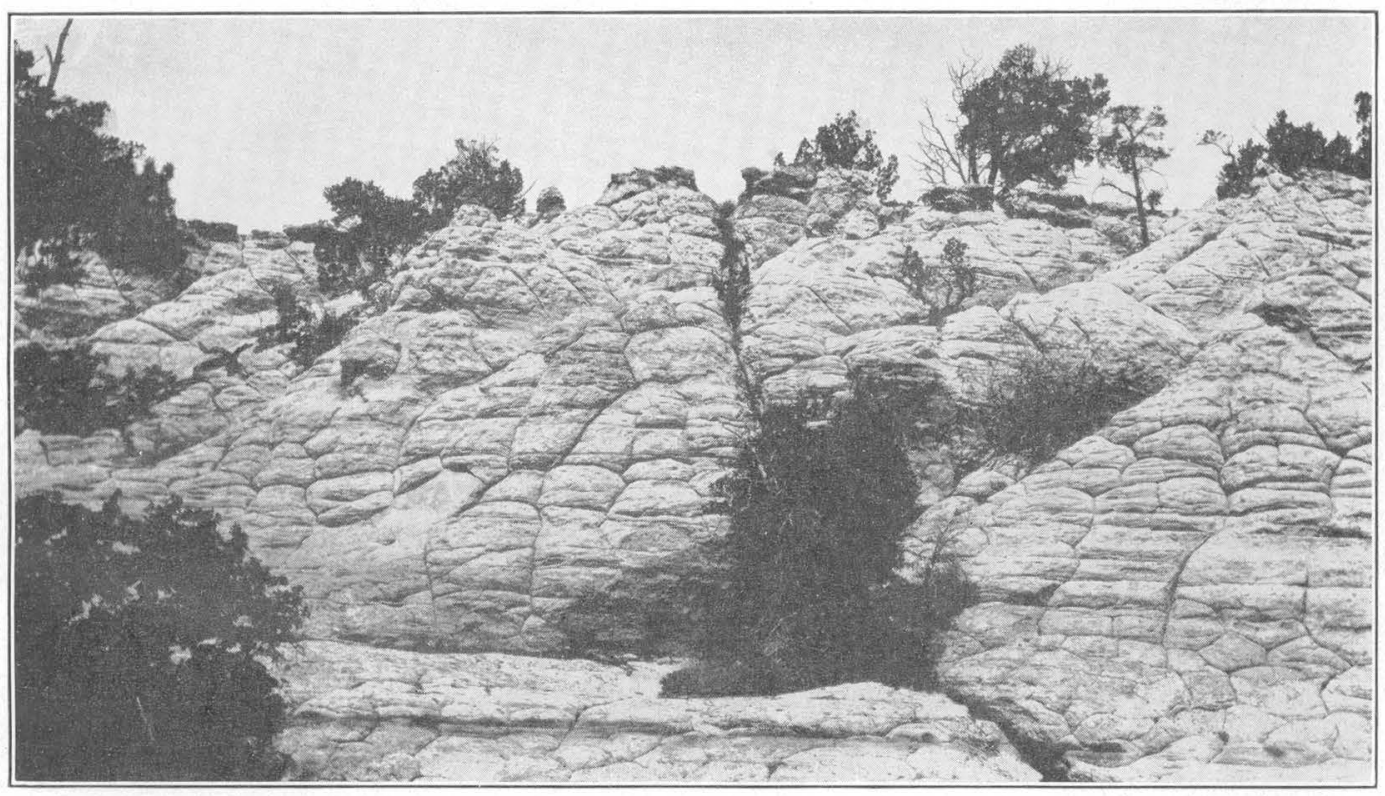

B. POLYGONAL JOINTING IN UPPER PART OF GALLUP SANDSTONE MEMBER.

Closer view at the locality shown in plate $29, \mathcal{A}$.

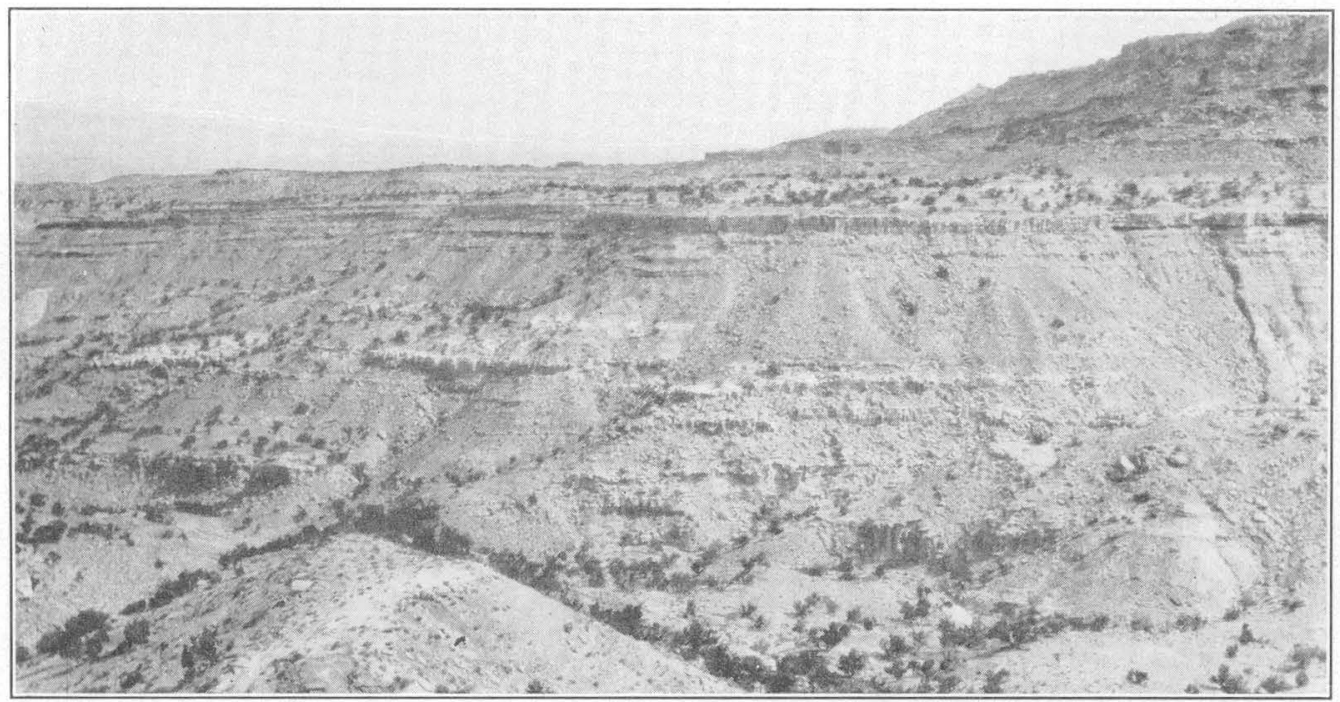

C. GIBSON COAL MEMBER OF MESAVERDE FORMATION WEST OF (LANDWARD FROM) AREA IN WHICH IT IS SPLIT BY THE HOSTA SANDSTONE MEMBER.

View in T. 17 N., R. 17 W. (northwest of point B in the diagram, plate 26), 


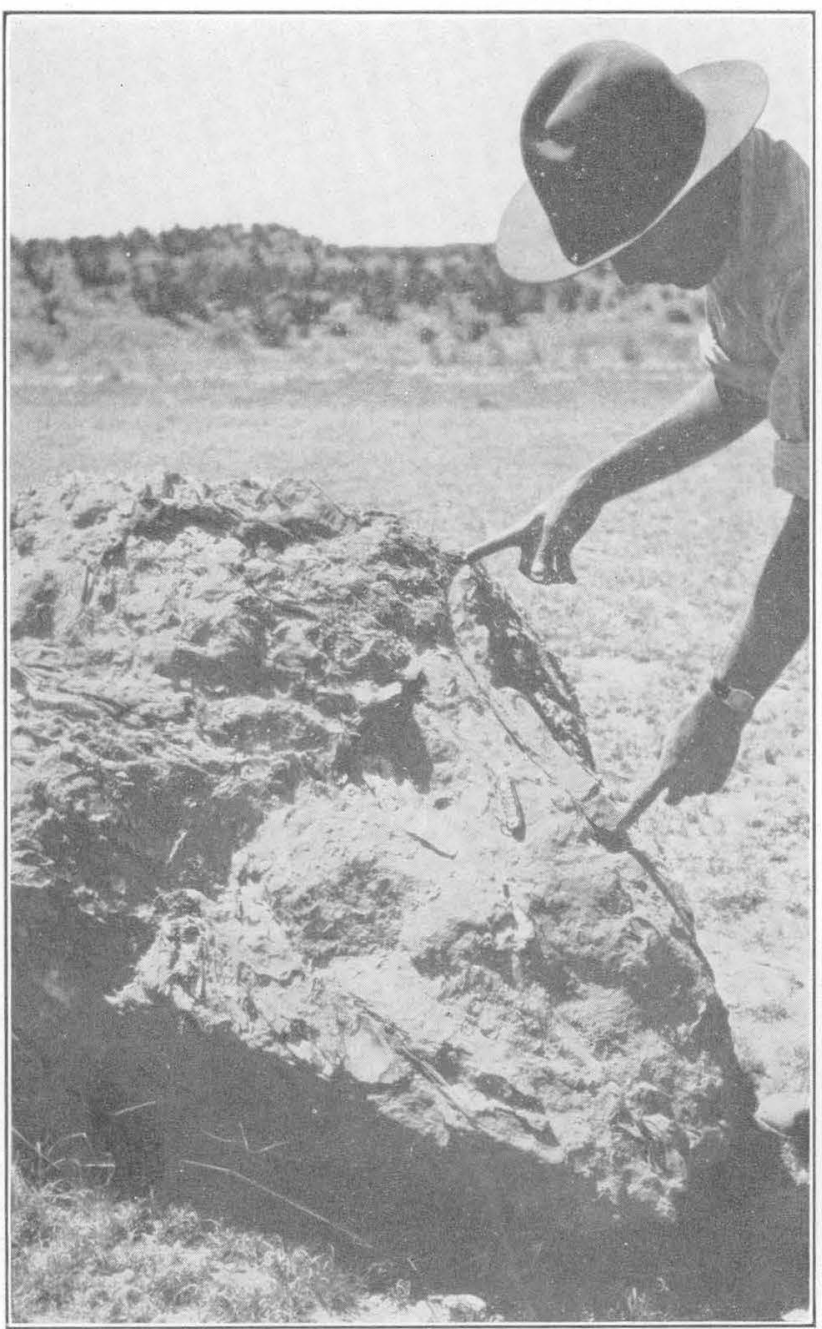

A. SANDY MARL COMPOSED LARGELY OF OSTREA SOLENISCUS. The indicated specimen is 18 inches long.

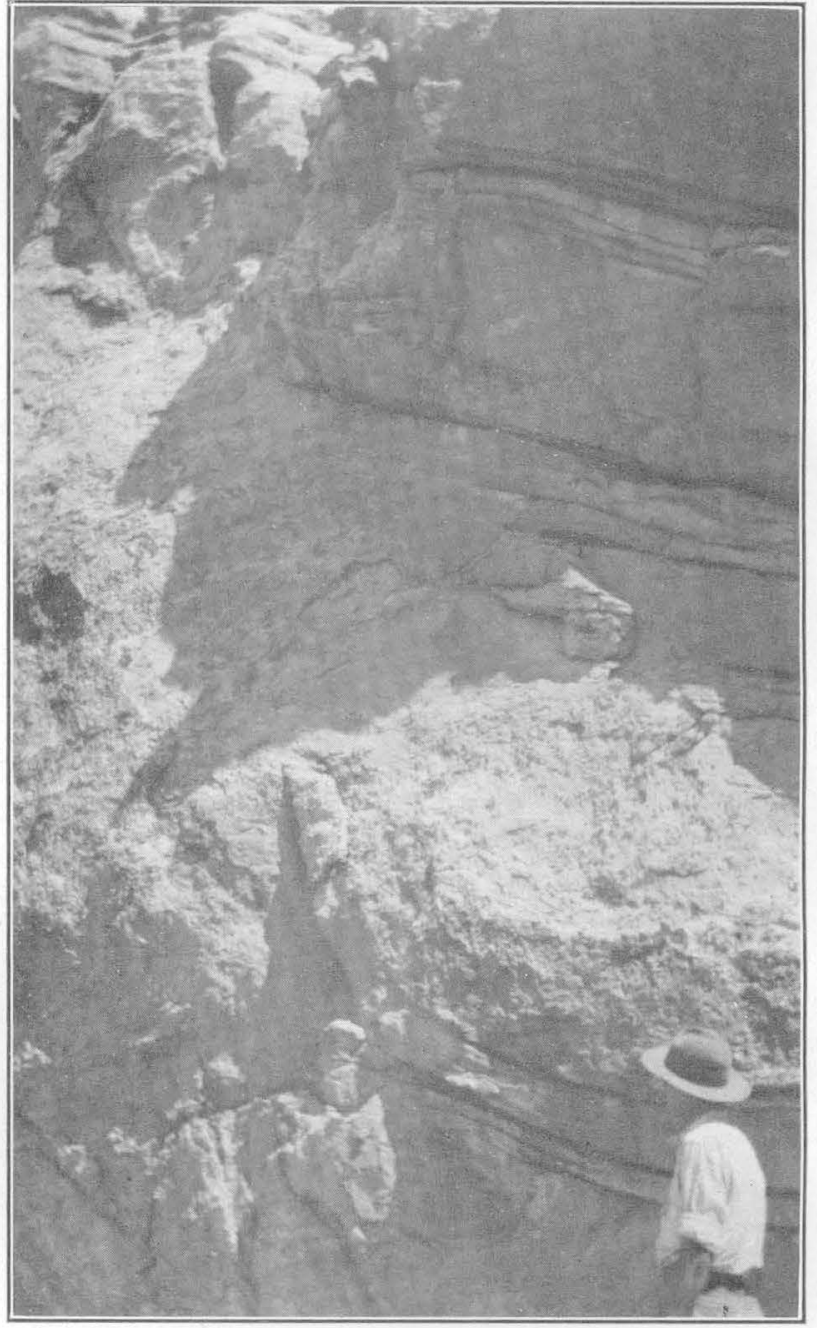

B. CLOSER VIEW OF THE OUTCROP SHOWN IN PLATE $30, C$.

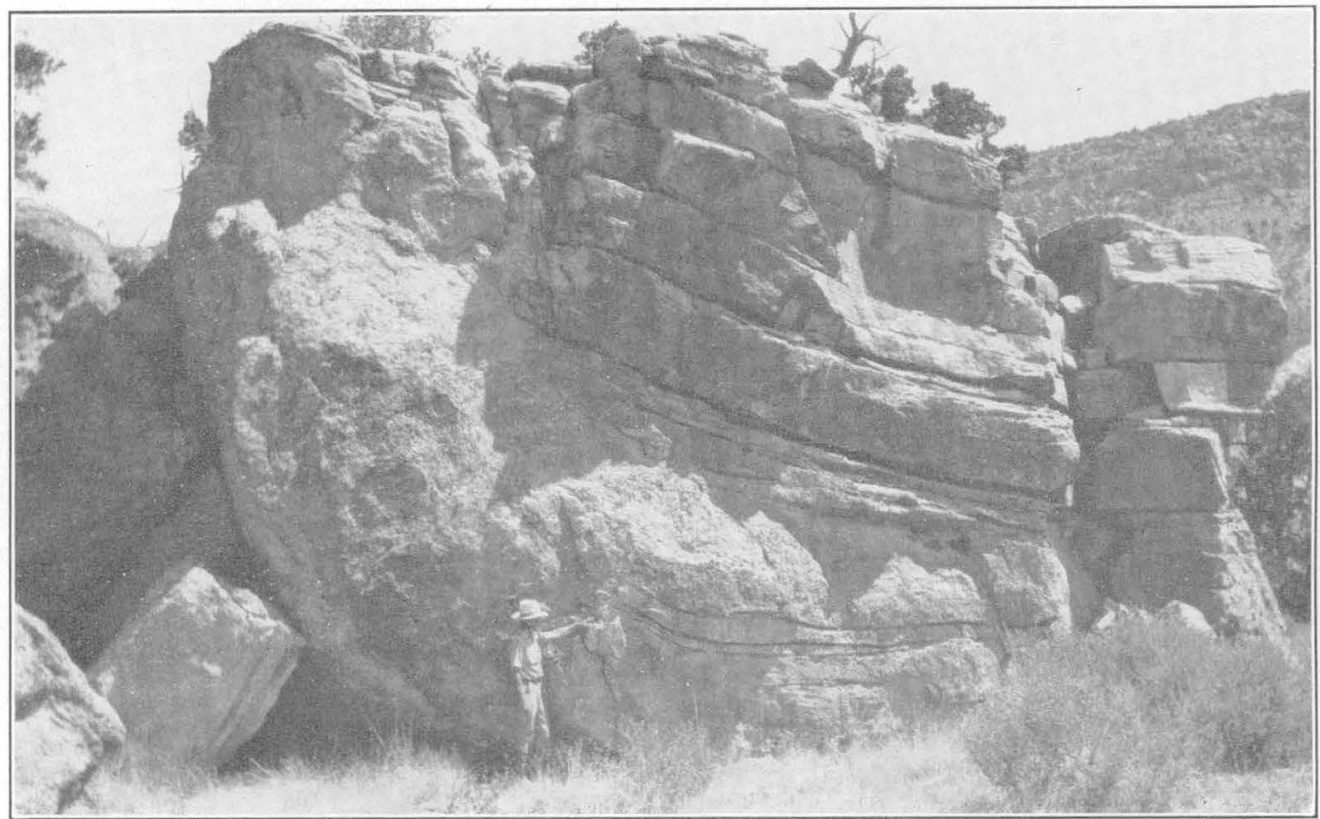

C. INTERTONGUING OF OSTREA SOLENISCUS MARL WITH LAYERS OF THE "STRAY SANDSTONE."

The marl is composed largely of Ostrea soleniscus; the bedded sandstone contains only seattered remains of that elongated oyster. View in sec. 9 , T. 14 N., R. 9 W, 
GEOLOGICAL SURVEY

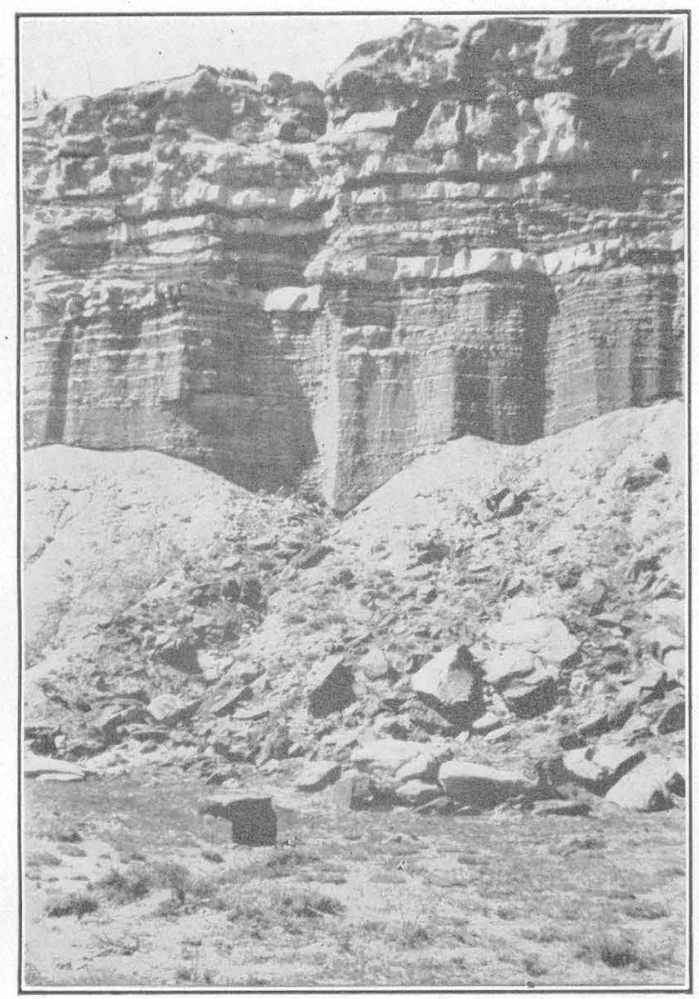

A. SATAN TONGUE OF MANCOS SHALE AND OVERLYING UPPER PART OF HOSTA SANDSTONE MEMBER OF MESAVERDE FORMATION. Note the transitional nature of the contact. In sec. 36, T. 18 N., R. 2 W. Photograph
by W. G. Pierce.
PROFESSIONAL PAPER 193 PLATE 31

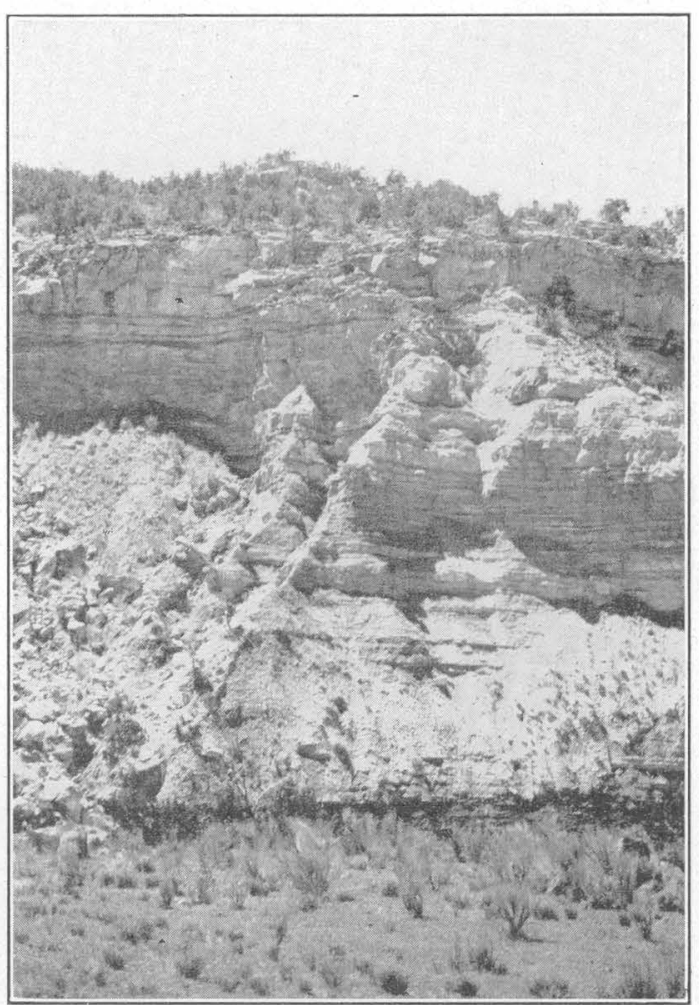

B. TRANSITION ZONE MARKING CONTACT BETWEEN MULATTO TONGUE OF MANCOS SHALE AND OYERLYING DALTON SANDSTONE MEMBER OF MESAVERDE FORMATION.

View on east side of Satan Pass in sec. 20, T. 16 N., R. 12 W. (near locality of section 9 in the diagram, plate 26)



C. HOSTA SANDSTONE MEMBER OF MESAVERDE FORMATION, SHOWING MODE OF WEATHERING OF UPPER PART. View in sec, 4, T. 17 N., R. 16 W. 
silndstone at section 27 in line GF and at point I of the line IJ. On the other hand it seems to be absent along the line HGKL, some 20 miles to the southwest, for no sandstone identifiable as the Hosta was found in the several hundred feet of the Gibson exposed at section 31 (in spur wall $\mathrm{e}^{\prime}$ ) and section 49 . The Hosta is therefore believed to have once extended landward to a line a few miles northeast of and roughly parallel to the line HGKL. It thickens seaward, or northeastward, and continues as a prominent sandstone until, near section 26 on line GF and section 43 on line IJ, it is split by the landward edge of the Satan tongue of the Mancos.

\section{ALIISON BARREN MEMBER}

Within the Gallup district the upper part of the Mesaverde formation has been removed by erosion so that only about 800 feet of beds remain above the Gibson coal member. These beds of continental origin, comprising lenticular sandstones and light-colored clay with little or no coal, were there named the Allison barren member. No upper stratigraphic limit of the member was indicated, and the lower limit varies from place to place with the variation in the horizon at which is found the highest coal bed of the Gibson.

The lower beds of the Allison are exposed along the northern edge of the field here discussed and also as a

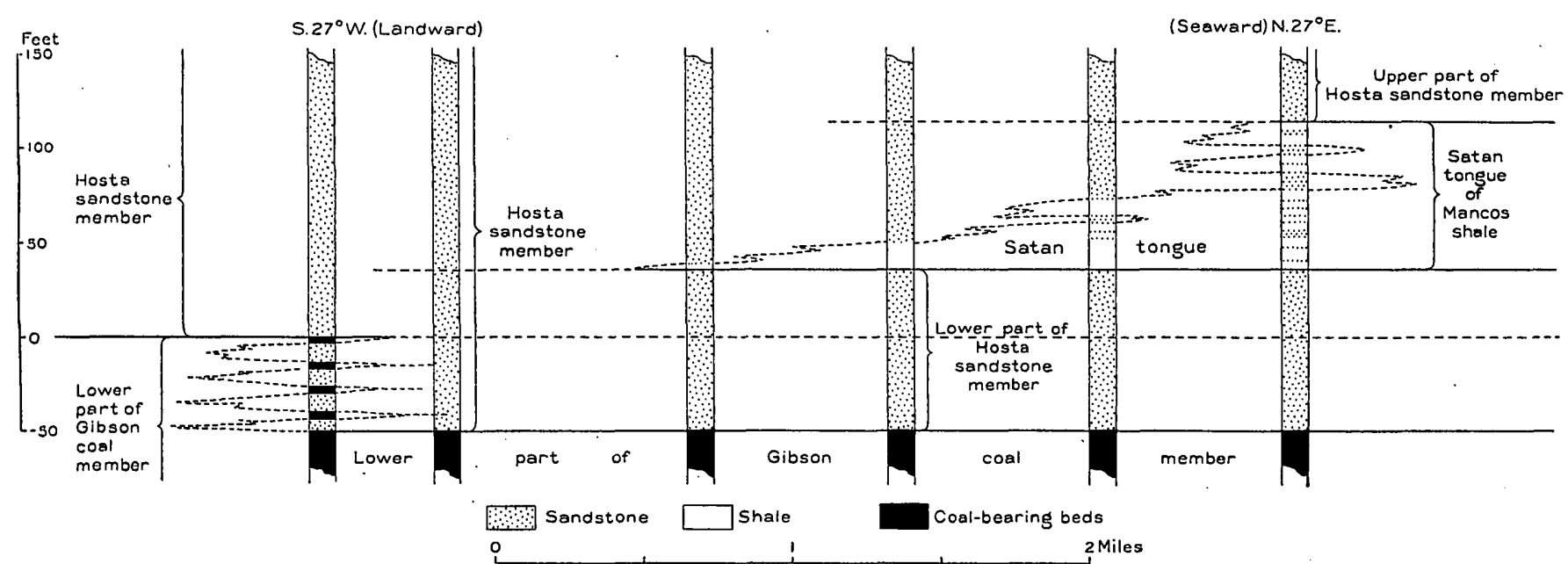

Frova 23.-Landward-seaward variations of the Hosta sandstone member of the Mesaverde formation and its relation to the Satan tongue of the Mancos shale. The diagram begins at the left with conditions representing those seen in the cliffs on the west side of Dalton Pass (at the locality of section 7 in wall $\mathrm{BC}$, pl. 26 ), and extends $\mathrm{N}$. $27^{\circ}$ L., directly seaward.

In the northeastern part of the field, along lines EF, GF, and IJ, the lower sandstone of the Hosta gradually loses its identity. By lateral gradation this sandstone and the Dalton sandstone member, together with the intervening coal-bearing beds of the lower Gibson, become represented by a single sandstone between the expanded Mulatto and Satan tongues. Where this sandstone dies out the Satan and Mulatto tongues merge with the main body of Mancos shale, and the upper sandstone of the Hosta, of lower Montana age, becomes the basal member of the Mesaverde formation.

Mr. Pike, an associate of the authors in the work here described, has subsequently, as part of a project sponsored by the Geological Society of America, traced the Mancos and Mesaverde formations from the Gallup district northward along the west side of the San Juan Basin into Colorado. He reports ${ }^{26}$ that the upper sandstone of the Hosta is essentially the stratigraphic equivalent of the Point Lookout sandstone, which, at the type locality in southwestern Colorado, is the basal formation of the Mesaverde group.

\footnotetext{
so Pike, William S., Jr., personal communication.
}

few local remnants within the field. However, they are of only slight and indirect significance in connection with the problems presented in this paper and need not be described. It is sufficient here to emphasize that the Hosta sandstone member is overlain by many hundreds of feet of continental beds, which are coal-bearing in the lower part (Gibson coal member) and barren above.

\section{DEPOSITIONAL HISTORY OF MANCOS AND MESAVERDE}

The variations and intertonguing of the Mancos shale and the Mesaverde formation in the southern part of the San Juan Basin and elsewhere are evidence of alternating processes of transgression and regression that were repeated several times during the Upper Cretaceous. The history, relations, and conditions of deposition of the various rock units, as set forth in the following pages in accordance with the depositional theories already outlined, are grouped for convenience under the several transgressive and regressive stages, each of which is designated by the names of the stratigraphic units that are related to it. 
DAKOTA (?)-MANCOS TRANSGRESSIVE STAGE

With the first deepening of the Upper Cretaceous trough, the sea waters that occupied it spread gradually over the sinking marginal lands. Upon the gently sloping surfaces of those lands were laid down the first material of the new series. In southern San Juan Basin, as in many other areas, it consisted of irregular, coarse, and in places conglomeratic sandstones, with associated layers of clay, carbonaceous shale, and locally some coal. From its lithologic character and its stratigraphic position this material in the New Mexico region has been called the Dakota (?) sandstone, in tentative correlation with the accepted Dakota of other regions. It seems evidently a record of sea beaches and of coastal lagoons and swamps.

As subsidence continued and the sea encroached farther upon the land, these zones of swamp and beach deposition gradually moved landward, their material being laid down transgressively over the old land surface. In turn their outer, earlier portions, now under deepening water, were slowly buried under off-shore muds that became the first beds of the transgressive Mancos shale. In the San Juan Basin the transgression was probably toward the southwest or west, and the strand line moved slowly in that direction across the San Juan Basin and on beyond it for an undetermined distance. With progressive subsidence, even though deposition may have been rapid enough to prevent the sea from ever attaining more than a relatively shallow depth, the duration and amount of the sinking were sufficient to permit the accumulation, in the area discussed in this report, of hundreds of feet of Mancos shale above the Dakota (?).

\section{MANCOS-TO-DILCO REGRESSIVE STAGE}

After a considerable time, however, subsidence of the trough and deepening of the water became slower and slower, and the debris, brought in by rivers from the southwest and moved along the shore by waves and currents, filled in the shallow, near-shore zone of the sea to and above water level and pushed the strand line outward-that is, northeastward. Farther seaward the deposition of marine mud continued, but along shore the sand was slowly built upward and outward over the earlier mud. Thus there came to be a regressive deposition of near-shore material upon off-shore material-sand upon marine mud.

Within this area the newer, coarser material appeared first near the southwest corner (see pl. 26, point A) as the basal beds of the Gallup sandstone member. The change from marine shale to overlying sandstone seems to have taken place gradually, for at that locality and at many other places the transition, is marked by 10 to 20 feet of alternating layers of sandstone and shale each an inch or two thick. Thus the first sands of the new regressive deposits must have come to rest on the earlier muds under water of appreciable depth, in which wave action was not strong enough to disturb the even, thin bedding of the alternating sand and mud. Above this transition zone, the main body of sand grew to a considerable thickness; the lower, major part apparently accumulated under water, and the upper part, which contains interbedded thin layers of clay and coal, accumulated just below and above the water surface.

As regression proceeded, the strand line was pushed gradually northeastward and a growing sheet of sand was spread out in that direction over the muds of the Mancos. Some minor interruptions to the regressive process are recorded by the local intertonguing of the lower part of the Gallup sandstone with corresponding small wedges of Mancos shale (for example, between points $\mathbf{A}$ and $\mathbf{B}$ in the diagram, pl. 26). However, in general the regression went on steadily, and the Gallup sandstone was extended northeastward across the area here discussed until it finally reached the approximate position of the line $1-1^{\prime}$, shown on the inset map, plate 26. The shale-sandstone contact cuts obliquely upward across time planes toward the northeast-that is, the uppermost shale and the lowest sands are progressively younger in that direction.

In the meantime, as the strand-line moved seaward, its earlier positions, marked by the accumulation of near-shore and beach sand, became the site of lagoons and coastal swamps. In these were laid down irregular bodies of sand and clay and of organic material. These deposits form the Dilco coal member, of evident continental origin. Their contact with the underlying Gallup sandstone is irregular from place to place, as might be expected; for the earlier sands, moved and built up by the action of waves, currents, and winds, naturally did not attain an even upper surface.

The Dilco deposits were formed in the third or coastal zone. As regression continued they in turn grew northeastward, extending out over the sands of the second or near-shore zone. Eventually they reached the approximate position shown by the line $2-2^{\prime}$ in the inset map, plate 26, falling short of the line reached by the Gallup sandstone.

\section{DILCO-MULATTO TRANSGRESSIVE STAGE}

By that time, however, regression was beginning to falter. There was a quickening of the rate of subsidence, and the sea, regaining its supremacy over the forces of deposition, began a new advance on the land. In this advance it moved in over the near-shore and continental deposits of the preceding regressive stage. Those deposits, whose outer (northeastern) portions had by that time reached only partial development, were interrupted in their growth by the new advance-a fact recorded by the marked northeastward thinning, practically to a feather edge, of the Gallup sandstone 
and Dilco coal members, as shown in the threedimensional diagram, plate 26 .

In the deeper waters seaward from the line 1-1' the deposition of Mancos shale had gone on continuously during the regressive stage: With the new advance of the sea, marine muds of the Mancos, the Mulatto tongue, were laid down transgressively over the earlier, coarser materials. The first muds, coming to rest in the area between the lines $1-1^{\prime}$ and $2-2^{\prime}$, lay directly on the thin Gallup sandstone. As transgression proceeded, southwestward from the line $2-2^{\prime}$ the basal muds of the Mulatto invasion were deposited at most places on the wedge of the Dilco coal member, which thickens gradually in that direction. However, in parts of the area shown by stippling on the inset map, the transgression was first marked by sandy and pebbly deposits, which in turn became overlain by the growing body of mud. These sandy and pebbly deposits, constituting the top part of the unit described on page 113 as the "stray sandstone," were evidently the coarser beach and nearshore debris laid down before the sea reached any considerable depth. As the deposition of marine muds advanced southwestward, the coastal zone in which deposition of the Dilco was continuing moved ahead of it.

The marine transgression just described continued for a much shorter time and reached southwestward a much shorter distance than did the earlier Dakota (?)-Mancos transgression. Water deep enough to receive and preserve offshore muds reached only the approximate position of the line 3-3' (inset map, plate 26), which thus forms the landward limit of the $\mathrm{Mu}$ latto tongue of the Mancos shale. Farther landward the deposition of the Dilco member-its irregular sands, clays, and coals-had gone on unabated.

Thus far two transgressive stages and an intervening regressive stage have been described. As the product of these three stages, the Gallup sandstone and the Dilco coal member formed a great tongue of near-shore and continental deposits wedging northeastward into a mass of the Mancos shale. At any one place a vertical stratigraphic section through the deposits records a completed cycle of sedimentation, from marine transgression through regression back to marine transgression. Beginning at the base, the rock sequence is (1) transgressive offshore muds (Mancos) ; (2) regressive offshore muds (Mancos); (3) regressive near-shore and beach sands (Gallup); (4) regressive continental deposits (Dilco); (5) transgressive continental deposits (Dilco) ; $(6)$ transgressive near-shore and beach sands and pebbles (top of the "stray sandstone," where present); and (7) transgressive offshore muds (Mancos). This cycle, according to the view that the writers have presented, was the result of trough subsidence that was continuous, but with varying rate, and was not caused by an alternately sinking and rising trough.

\section{MULATTO-T0-LOWER GIBSON REGRESSIVE STAGE}

With a second slowing down of the rate of subsidence there began a new regressive stage which, though somewhat comparable to the first, proceeded to a more complete and somewhat more complex development within the southern part of the San Juan Basin.

The period of change from transgression to regression was marked in the southwestern part of the area (near sec. 2 in the three-dimensional diagram, pl. 26) by the formation of a sandstone body about 180 feet thick. Toward the southwest this sandstone grades laterally into the upper part of the Dilco near point $\mathrm{A}$; and toward the east and northeast the lower part of the sandstone grades into the Mulatto tongue of the Mancos shale (between secs. 5 and 6). This thick sandstone deposit was formed near a relatively stationary strand line, during a period when subsidence and deposition were approximately balanced and growth was upward rather than landward or seaward. At one time, however, represented by the intertonguing of sandstone and shale between secs. 5 and 6 , there was an intermediate minor regression and transgression.

From the vicinity of section 5 the upper or main part of the Dalton sandstone continues far to the east. with a generally uniform thickness of about 100 feet. The change from Mulatto to the overlying Dalton, just as from Mancos to the overlying Gallup, is marked at many places by a transition zone of alternating thin layers of sandstone and shale. (See pl. 31, B.) The presence of marine fossils in the lower part of the Dalton, their absence from its upper part, the more variable composition of that upper part, and the very irregular upper surface of the sandstone, are additional evidence of its mode of origin, the first sand being laid down on earlier mud in near-shore but relatively quiet water, and the later sand being built up to and above the water level.

As the body of sand grew upward and northeastward, pushing the strand line seaward before it, the landward parts of its irregular upper surface became covered progressively toward the northeast by beds of the continental type. Eastward from section 6 (see pl. 26) the Dalton is overlain by the lower part of the Gibson coal member, formed in the coastal zone. Eventually the Dalton sandstone reached the approximate position of line $4-4^{\prime}$, and the lower part of the overlying Gibson coal member reached about to the line $5-5^{\prime}$, as shown on the inset map, pl. 26. The attainment of that growth brought to a close the second principal regression herein discussed.

At the conclusion of that second regression the shore line lay near the position of line 5-5' for a considerable period, with only minor oscillations landward and seaward. During that period the rate of subsidence was more rapid so that it almost exactly balanced the rate of deposition of 'sand in the near-shore zone: The 
existence of such a balance between subsidence and deposition brought about in the near-shore zone the formation of a thick body of sand. This sand intertongued landward with the Gibson coal member, which was growing in the swamps behind it, and also inter- tween the uppermost Dilco to the west and the lower part of the Gibson east of section 6, as might be expected with regular seaward movement of the several zones. The mapped and hypothetical conditions in this vicinity are contrasted graphically in figure 24.
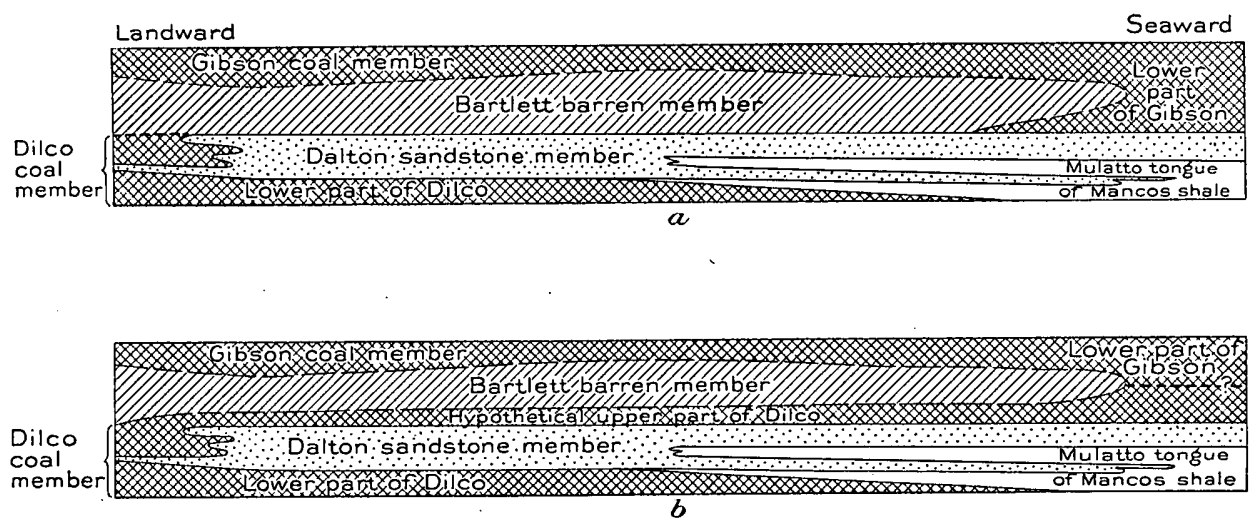

Figure 24.-Diagram showing actual and hypothetical relations of the Dilco, Dalton, and Bartlett members. $a$, Bartlett barren member resting directly on the Dalton sandstone member for several miles (part of the diagram near point $B$ in pl. 26); $b$, expectable continuation of regressive coal-bearing beds above the Dalton sandstone.

tongued seaward with marine shales of the Mancos. (See beds in the vicinity of secs. 21 and 22 in the wall DEF and of section 24 in the wall GF.) This balance persisted until further acceleration of subsidence in relation to deposition initiated the succeeding transgressive movement.

In the meantime, in the Gallup district and near point $\mathbf{A}$ in the diagram, plate 26, a further effect of the regression was being recorded. As the coastal zone moved seaward, its last deposits at the west, the uppermost beds of the Dilco coal member, became covered gradually by the first beds of the next landward or flood-plain zone in which the Bartlett barren member was laid down. Inasmuch as the two zones merged irregularly and transitionally, the lithologic changes in a sequence of their deposits are gradual, and a boundary between the zones is difficult to determine. Thus, although the Bartlett throughout is essentially lacking in coal, its marginal beds otherwise closely resemble the materials of the Dilco. Consequently, at places in the coastal zone where coal may not have been formed and preserved, some beds may have been mapped as Bartlett rather than Dilco, because for mapping purposes the members were differentiated arbitrarily by the presence or absence of workable coals. Thus, in general, the mapped boundary between the members marks only approximately the boundary between the third and fourth zones of deposition and in places may miss it by a stratigraphic interval of as much as a hundred feet. Though tracing of individual beds did not so indicate, this is possibly the reason why for a few miles west of section 6 the Bartlett, as mapped, rests directly upon the Dalton sandstone rather than upon an intervening sheet of coal-bearing material, which would have formed a connection be-
If coal-bearing beds had continued unbroken between the Dalton and the Bartlett in this vicinity, the sequence would have resembled that of the upper Hosta, upper Gibson, and Allison strata shown near point B in the diagram, plate 26 .

\section{IOWER GIBSON-TO-SATAN TRANSGRESSIVE STAGE}

The next transgression and the subsequent regression reached a fuller development in the southern part of the San Juan Basin and were recorded by a more complete sedimentary sequence than those of the earlier stages. As shown in the several main and spur walls of the cross-section diagram in plate 26, the materials were laid down and preserved with striking uniformity throughout the area.

During the preceding regressive stage, deposition of the Mancos shale had gone on steadily in the deeper waters northeast of the line $44^{\prime}$. The change from regression to transgression was not abrupt; instead, as a.iready pointed: out, there was a considerable intervening period of approximate balance between subsidence and deposition. During that period of balance the strand line remained relatively stationary, and there was formed in the near-shore zone the great body of sandstone that is represented between point $\mathrm{E}$ and section 22 in the wall EF, near section 24 in the wall GF, and near section 46 in the wall IJ, in plate 26 . Seaward, the deposition of shale' continued. Inland, through a broad area, there was further accumulation of the coal-bearing beds of the lower Gibson; and far to the west, near point B, the latest beds of the Bartlett barren member were being formed.

As trough subsidence became still faster and the balance was overcome, actual transgression began and the deposits of each zone spread southwestward over 
the material of the next landward zone. The coalbearing beds of the lower Gibson extended inland over the Bartlett to and beyond the limits of the area at point A. Above the coal-bearing beds spread a growing sheet of sand, which formed the lower part of the Hosta sandstone member and which eventually reached the approximate position of the line 6-6' (inset map, pl. 26). As a final phase of the transgression, with deepening water the muds of the Satan tongue of the Mancos grew inward upon the earlier sands, finally reaching as far as the line $7-7^{\prime}$, some 10 to 15 miles short of the line reached by those sands. The straightness of line $7-7^{\prime}$ for so many miles is noteworthy; it seems to reflect a very straight strand line caused by even subsidence and the advance of the sea over a nearly flat, featureless plain of the earlier sand. If any rivers entered the sea along that strand line, their small size, their relative freedom from debris, or the power of waves and currents to spread materials evenly along shore must have prevented the formation of deltas or other breaks in the regular deposition. Despite the apparently even subsidence at that stage, however, it should be observed that the line $7-7^{\prime}$ is not parallel with the line $3-3^{\prime}$, which marks the extreme landward extent of the next earlier transgression of marine mudthe Mulatto tongue. Indeed, the gradual change in direction of the series of lines $1-1^{\prime}$ to $7-7^{\prime}$ from about $\mathrm{N}$. $34^{\circ} \mathrm{W}$. to about N. $63^{\circ} \mathrm{W}$. would seem to indicate that the strand line, in its landward and seaward shifts, gradually assumed a more westerly direction through a slow regional differential warping.

\section{SATAN-TO-ALLISON REGRESSIVE STAGE}

After transgression of the Satan tongue of the Mancos shale, there began the last regression recorded by the rocks now preserved in this southernmost part of the San Juan Basin. The processes and sequence of events were essentially the same as in the earlier regressive stages. The muds of the Mancos, growing upward and northeastward, completed the wedge of shale, the Satan tongue, that thickens steadily in that direction. The Hosta sandstone, which between the lines $6-6$ and $7-7^{\prime}$ forms a single thick sand body, likewise grew upward and northeastward, forcing the sea waters outward before it; its upper part, thus deposited with transitional contact above the shale of the Satan tongue (see pl. $31, A)$, gradually extended to and far beyond the northeastern limits of the area herein discussed. In turn, its upper surface became the site of lagoons and coastal swamps in which were laid down and gradually extended outward those coal-bearing beds that represent the upper part of the Gibson coal member. Finally, these upper coal-bearing beds also extended to and beyond the northeastern limits of the field, and the whole mass gradually became buried beneath many hundreds of feet of continental, predominantly flood-plain debris of the Allison barren member, which marked the last phase of this major regression. 


\section{INDEX}

Alistrinct: -

AlHison baren member of Mesaverde formation, character and occurrence of conditions of deposition of:_....... 119

Burtlett barren member of Mesaverde formation, character and occurrence of

conditions of deposition of

$111,113-114,08$

luteral variations of

Book Cliffs, Utah-Colo., character of Mancos-Mesaverde boundary in

Carlile fossils, occurrence of

Constal zone of deposition, defined

Cross, Whitman, quoted

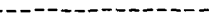

Cycles of sedimentation, sequence of formations in

n-no

Dakota (?) sandstone, stratigraphic relations of 108, 116 Dakota (?)-Mancos transgressive stage, conditions of deposition during -

Daiton Pass forlions at 116 Dalton Pass, formations at sandstone member of Mesaverde formation, character and occurrence of 112,113 , pls. $28, A, 31, B$

conditions of deposition of 12,113, pls. $28, A, 31, B$

entent of of deposition of

lateral variations of

Debris, rate of supply of

Depositional history, Mancos and Mesaverde-_... 116-119

Depositional theory, discussed..._._.

Dilco coal member of Mesaverde formation, character and occurrence of _..._......... 108, 111, 112-113

conditions of deposition of ........ 116-117, 118

extent of ...

lateral variations of

Dilco-Mulatto transgressive stage, conditions of deposition during-_- 116-117

Field studies in the area 106-107

Gallup sandstone member of Mesaverde formation, character and occurrence of - 108 $109,111-112$, pls. $27, B, 28,29, A, B$

conditions of deposition of correlation of - 112 extent of lateral variations of -..._._._. 111-112, pls. 26 (in pocket), $28, B$ Gibson coal member of Mesaverde formation, character and occurrence of conditions of deposition of 111,114, pls. $28, C, 29, O$ extent of -._._. 117-118, 119, pl. 26 (in pocket) lateral variations of Gryphaea newberryi zone, position of Hogback, formations of -._._._._._._. 109, 111, 112, 113, 114, pl. 27

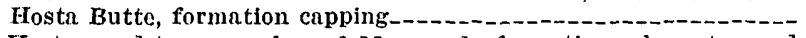
Hosta sandstone member of Mesaverde formation, character and occurrence of conditions of deposition of - 119 correlation of - - 115 extent of lateral variations of
Intertomguing $\quad$ Page $105,106,108,110,111,112,113,114-115,117$

Landward zone of deposition, defined_._. 104 Lower Gibson-to-Satan transgressive stage, conditions of deposi-

tion during _._._. See also Gibson coal member of Mesaverde formation.

Mancos shale, character, age, and boundaries of 108,110, pls. $27,28,31, A, B$ $\begin{array}{ll}\text { name and type locality of } & 108 \\ & \end{array}$ section of Mancos-Mesaverde boundar. 26 (in pocket), 27, $A, B$ Mancos-to-Dilco regressive stage, conditions of deposition during- 116 Mesaverde formation, character, age, and boundaries of $108,110-111,115$, pls. 26 (in pocket), 27

divisions of -................. 111-115, pls. 27, $B, 28-31$

name and type locality of Miguel Creek dome, well in Mulatto tongue of Mancos shale, character and occurrence of -- 108, 110,113 , pls. $28, A, 31, B$

conditions of deposition of - 117 extent and thickness of -

Mulatto-to-lower Gibson regressive stage, conditions of deposi-
tion during

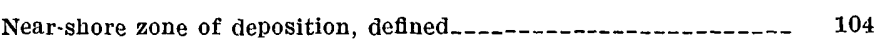
Niobrara fossils, occurrence of

Off-shore zone of deposition, defined__._. 104 Ostrea soleniscus, occurrence-of

Profile of equilibrium, defined__.__- 103 "Punta de la Mesa sandstone," correlation of Regressive stages of deposition, conditions governing--. 103-105, pl. 25 defined examples of Rock Springs uplift, Wyo., character of Mancos-Mesaverde boundary in-... 105 Satan tongue of Mancos shale, character and occurrence of $110,113,114$, pls. 26 (in pocket) $28, C, 31, A$ conditions of deposition of - 119 extent and thickness of -... Satan-to-Allison regressive stage, conditions of deposition during $\quad 119$ Strand-line migrations, examples of significance of

"Stray sandstone" of Mesaverde formation, character and occurrence of conditions of deposition of extent of

Transgressive stages of deposition, conditions governing- 104-105, pl. 25 defined. examples of

Trough, rising . sinking or subsiding -._._._._._-_-_-_ 102, 103, 104, 116-119 Upper Cretaceous, features of

Upper Cretaceous geosyncline, features of

Zones of deposition, defined-104 movements of, described relation of, to planes of time equivalence 